\title{
Rebellion in south-western England and the Welsh marches, 1215-17*
}

\author{
Paul Latimer \\ Bilkent University
}

\begin{abstract}
This study attempts a reassessment of the rebellion of I2 I 5-I7 in two regions: southwestern England and the Welsh marches. After examining the historiography of the I2I5-I7 conflict and some problems with the evidence, the article deals with the two regions in turn. In the first, the rebellion is found to be somewhat stronger than has been appreciated and to be, to a considerable extent, one of local county communities, rather than of great barons. In the second, the rebellion is seen as much stronger than it has been portrayed, although here the great rebel barons play a significant role. In both regions, the rebellion appears as one directed against an exploitative and intrusive central government and its aggressive curial servants, while also, in the outcome of the rebellion, a degree of common interest between the rebels and baronial loyalists is suggested. Overall, although there are some contrasts between the two regions, the study stresses the elements of a common cause in the rebellion.
\end{abstract}

In I96I, J. C. Holt's groundbreaking study, The Northerners, based on a detailed analysis drawn from one very important region, offered an interpretation of the origins and course of the I2 Is revolt against King John and of the civil war that followed. ${ }^{1}$ His conclusions, which in most respects have remained unchallenged, were that the revolt in the north derived from a level of royal financial pressure unprecedented in that region, an over-ruthless political exploitation of the consequent debts, and resentment at King John's aggressive use of patronage to favour a narrow circle of the 'king's friends'. This latter category included some local men, but also those who were from outside the region and, in some cases, from outside England. Grievances over these men and their behaviour are not easily separable from the financial pressure. If 'the harshness and corruption of some administrators' was a grievance, this was partly because of 'the harshness of the policies which they had in any case

* The author would like to thank the staff of the Institute of Historical Research, where most of the research for this article was done.

${ }^{1}$ J. C. Holt, The Northerners: a Study in the Reign of King John (Oxford, I96I). 
to enforce'. ${ }^{2}$ Holt also concluded, with many qualifications, that the rebellion was essentially a revolt of northern barons and that, by and large, northern knights followed their lords, rebel or loyalist. ${ }^{3}$ This last point has come in for some criticism, to which this article will turn later.

Since I96I little research has been done to complement Holt's work with other regional studies. ${ }^{4}$ Specifically, with regard to the present article, there has been no detailed analysis of the revolt in south-western England and the Welsh marches. ${ }^{5}$ Surprisingly, too, we still lack a full and detailed study dedicated to the conflicts of the period I2I5-I7 as a whole. Existing accounts are contained only in general works, in studies of the reign of King John or of the minority of Henry III, or in works concentrating their attention on Magna Carta. It is understandable that many of these have not dealt with south-western England or the Welsh marches at much length.

The lack of a good account of the revolt in south-western England and the Welsh marches has not altogether been the fault of historians. The narrative primary sources from England are themselves, except in the case of a few episodes, scant in their coverage of the area. Concerning the Welsh marches, the Welsh narrative sources are much better, although their focus is naturally on the Welsh princes. This evidence has been used more for the history of Wales than in discussions of the wider rebellion against King John and his son. In this respect, J. E. Lloyd's account is still the fullest. ${ }^{6}$

Before the nineteen-sixties, historians of King John and of the circumstances surrounding Magna Carta were at least reasonably fair in devoting space to the western rebels. ${ }^{7}$ Subsequently, however, historians

${ }^{2}$ Holt, Northerners, pp. 33-4, I96, 216-I 7, 223-5, 240, 25I-3, 255.

${ }^{3}$ Holt, Northerners, pp. 35-60.

${ }^{4}$ An exception is B. J. Feeney, 'East Anglian opposition to King John' (unpublished University of Reading Ph.D. thesis, I973). Kathryn Faulkner's study, although specifically on the knights of Bedfordshire, Cambridgeshire, Huntingdonshire and Northamptonshire, might also be mentioned here (K. Faulkner, 'The knights in the Magna Carta civil war', in ThirteenthCentury England, VIII, ed. M. Prestwich, R. H. Britnell and R. Frame (Woodbridge, 200I), pp. I-I2. For a very early, although brief, attempt at a regional analysis of the rebellion centred on East Anglia, see F. M. Powicke, Stephen Langton (Oxford, I928), app. V, 'The Twenty-Five barons of the charter', pp. 207-I3.

5 'South-western England' here comprises the counties of Cornwall, Devon, Dorset, Somerset and Wiltshire; the 'Welsh marches' is taken to include the English counties of Gloucestershire, Worcestershire, Herefordshire, Shropshire and Cheshire, together with the marcher lordships in Wales itself. This is a broader interpretation of the term than usual, but convenient here.

${ }^{6} \mathrm{~J}$. E. Lloyd, A History of Wales: from the Earliest Times to the Edwardian Conquest (3rd edn., 2 vols., I939), ii. 642-54. See also R. R. Davies, The Age of Conquest: Wales 1063-1415 (Oxford, I987), pp. 242-3, 296-7; and I. W. Rowlands, 'King John and Wales', in King John: New Interpretations, ed. S. D. Church (Woodbridge, I999), pp. 273-87, at pp. $285-7$.

7 K. Norgate, John Lackland (I887), pp. 230-2, 274-5; S. Painter, The Reign of King John (Baltimore, Md., I949), pp. 289-90, 357-9; C. R. Cheney, 'The eve of Magna Carta', Bull. John Rylands Libr., xxxviii (I956), 3 I I-4I, at pp. 3I4-I5, 32I-2. Up to the death of King John, Painter's is still the best account of the conflict countrywide. See also, S. Painter, William Marshal: Knight-Errant, Baron, and Regent of England (Baltimore, Md., 1933), pp. 207-8. 
of the period up to John's death have offered scant and somewhat dismissive accounts. In W. L. Warren's King John, remarks on the situation in western England and Wales are limited to brief references to Giles de Braose, bishop of Hereford, to the containment of the Welsh by the earls of Pembroke and Chester, and to the secure hold of those earls on the west midlands. ${ }^{8}$ Warren also produced a very misleading map that showed the royalists in control not only of the whole of western England south of the River Lune in Lancashire, but also of the whole of south Wales. ${ }^{9}$ Ralph V. Turner, in his King John, scarcely mentions a rebellion in the west of England at all. The only rebels there remarked upon are Giles de Braose, noted as the sole bishop on the rebel side rather than because of the location of his lands, and, after Prince Louis's invasion, the earl of Salisbury. 'Welsh chieftains' appear only to be negotiated with in the summer of I2I6, while at King John's death it is bluntly stated that 'he controlled the west of England', while the earls of Pembroke and Chester 'controlled the Welsh marches'. ${ }^{10}$ Holt, in his Magna Carta, stated that 'in the civil war, the marches scarcely faltered in their loyalty to the king', which this author will argue is an untenable assertion. His account of the early stages of the rebellion, apart from referring to John's attempted conciliation of Giles de Braose, only mentioned northerners and men from East Anglia. ${ }^{11}$

For the war in I2I6-I7 after King John's death, the more recent work has, in contrast, been fuller and more balanced than older studies. ${ }^{12} \mathrm{D}$. A. Carpenter, who in The Minority of Henry III has the best recent account, stresses the security of the loyalist bases in western England and the strength of a loyalist 'cordon of Marcher barons', but he does acknowledge the threat from Llywelyn and Reginald de Braose. Carpenter notes the importance, in local terms, of the earl of Salisbury's rebellion and return to loyalty. ${ }^{13}$ Yet, in what is essentially a prologue to the main body of his book, Carpenter's references to the situation in the west of England are necessarily brief.

Little attempt has been made to explain the causes of rebellion in the west in terms of the common local concerns of the rebels there.

${ }^{8}$ W. L. Warren, King John (I96I), pp. 247-8, 253.

9 Warren, King John, p. 250.

${ }^{10}$ R. V. Turner, King John (I994), pp. 252, 255, 257.

11 J. C. Holt, Magna Carta (2nd edn., Cambridge, I992), pp. 204, 232, 234. In Holt's Northerners, one would naturally not expect much mention of the rebels of western England. However, it is worth noting that in his initial discussion of the term 'Northerners' and of the place of northern rebels among the rebels as a whole, the only other groups mentioned are those from East Anglia and from the Home Counties (Holt, Northerners, p. 9).

${ }^{12}$ For these older accounts, see the minimal references to western England in K. Norgate, The Minority of Henry the Third (I9I2), pp. 6, 90; and the glowing assessment of Henry III's prospects at his accession in F. M. Powicke, King Henry III and the Lord Edward: the Community of the Realm in the 13th Century (2 vols., Oxford, I947), i. I and F. M. Powicke, The Thirteenth Century, 1216-1307 (2nd edn., Oxford, I962), pp. I-2.

13 D. A. Carpenter, The Minority of Henry III (I990), pp. 20, 26-7, 30-I, 35. 
Addressing the question of loyalists rather than rebels, Painter suggested that the barons of the Welsh marches were largely loyal because the Welsh were in revolt. ${ }^{14}$ This is a rather unconvincing argument given that the rebel Welsh were capable at least of offering security to the Welsh lands of marcher rebels. The argument is also premised on the solidity or near-solidity of marcher loyalty, a questionable assertion that, as we have seen above, is not unique to Painter. In explaining the loyal faction that undoubtedly did exist in the Welsh marches, Warren's suggestions on the role of Irish affairs seem to represent a more promising approach than Painter's. ${ }^{15}$ Another route taken by Painter in attempting to explain the local patterns of rebellion and loyalty was that of investigating the interconnections between rebel barons. However, he focused here more on the eastern and northern rebels, and even with these the analysis proved ultimately inconclusive. ${ }^{16}$

Painter generally held to his view that the local patterns of loyalty or rebellion could not be explained on a geographical basis. Instead, 'the dominant factor was the attitude of the great barons' ${ }^{17}$ In linking the individual decisions of these great barons with rebellion or loyalty further down the social scale, Painter did not press the argument for an explicitly feudal relationship. Although he was confident that the rebellion was 'largely baronial', he mentioned only the possibility that many of the lesser rebels were acting as vassals of rebel lords; he was sceptical of historians' ability to demonstrate this. ${ }^{18}$ Holt, in his chapter 'The northern knights' in The Northerners, laid out at considerable length the difficulties in ascertaining and analysing the behaviour of knights, but his conclusions were more forceful than Painter's: 'Many knights simply followed their lord, either against or for the King'; 'the rebellion revealed broadly feudal characteristics'; and 'the general impression of the evidence is that the great rebel lords were followed by the men whom they might reasonably regard as their particular tenants almost to a man'. Even the revolt of tenants of the honour of Richmond, rebelling against their lord, 'bore a feudal and tenurial stamp'. ${ }^{19}$

Contrary views have been presented. Hugh M. Thomas, in his study of the Yorkshire gentry, accepted that honorial ties had 'a moderate

${ }^{14}$ Painter, Reign of King John, p. 290.

${ }^{15}$ W. L. Warren, 'Painter's King John - 40 years on', Haskins Society Jour., i (I989), I-9, at pp. 3-4; W. L. Warren, 'King John and Ireland', in England and Ireland in the Later Middle Ages: Essays in Honour of Jocelyn Otway-Ruthven, ed. J. F. Lydon (Dublin, I98I), pp. 26-42, at pp. 27,32 .

${ }_{17}^{16}$ Painter, Reign of King John, pp. 290-6.

${ }^{17}$ Painter, Reign of King John, p. 290.

${ }_{18}$ Painter, Reign of King John, pp. 298-9.

${ }^{19}$ Holt, Northerners, pp. 35, 36, 43, 49. These views have received recent support from Carpenter, although without any new evidence on the behaviour of knights I2I5-I7 (D. A. Carpenter, 'The second century of English feudalism', Past \& Present, clxviii (2000), 30-7I, at pp. 50, 545, 64-5, 69-70; D. A. Carpenter, The Struggle for Mastery: Britain 1066-1284 (2003), p. 288). 
influence on loyalties in the rebellion' and that 'lords had influence on at least some vassals', but argued against the strength of the evidence for honorial solidarity, also criticizing, with some force, one of Holt's main examples, the behaviour of the Mowbray tenants. ${ }^{20}$ Thomas therefore placed more stress on the Yorkshire gentry's own 'grievances and burdens' in explaining their participation in the revolt. ${ }^{21}$ Kathryn Faulkner, in her study of the knights of Bedfordshire, Cambridgeshire, Huntingdonshire and Northamptonshire in I2I5-I7, addressed the question of whether knights predominantly followed their lords in the conflict. Her conclusion on this point was that, while ties of lordship could still be a factor, 'many knights were able to choose their own course in I2I5-I7, and that in doing so they showed a bias towards rebellion'. ${ }^{22}$

The problem with this debate is the nature of the evidence. Many of its difficulties have already been outlined by Painter, Holt, Thomas and Faulkner. All sides accept that tenurial bonds could play a part in determining whether a knight rebelled or remained loyal to the king. Yet, as Holt himself noted: 'Examples of tenurial solidarity are easy to find. So also are examples of the opposite. ${ }^{23}$ The question as to how far tenurial bonds were in general important can only be answered either statistically or impressionistically. The evidence of reversi lists, with their acknowledged gaps, can bear very little statistical weight, while impressionistic conclusions are both drawn from, and better applied to, a wider debate about the strength or weakness of feudal structures in the late twelfth and early thirteenth centuries. ${ }^{24}$

There is no attempt here to address systematically for south-western England and the Welsh marches the question of whether men followed their lords in rebellion or loyalty. This is partly for a practical reason: because of the size of the area, the number of knightly tenants is too great for all to be investigated. Even were it to be practicable, however, it is doubtful whether such an attempt could do more than multiply the

${ }^{20}$ H. M. Thomas, Vassals, Heiresses, Crusaders, and Thugs: the Gentry of Angevin Yorkshire, 1154-1216 (Philadelphia, Pa., 1993), pp. 45-7. Thomas also criticizes Holt's interpretation of the honour of Richmond as an example of collective action by tenants of an honour (p. 46, n. I07). In his review of Thomas's book, Holt adds another example of what he sees as 'l'importance continue de la grande baronnie et des liens entre seigneur et vassal' in I2 I 5-I7. He also criticizes Thomas's use of witness-lists to demonstrate the decline of honorial ties, arguing that Thomas does not examine the witness-lists and their differing and changing contexts closely enough ('Bibliographie', Cahiers de Civilisation Médiévale, xxxviii (I995), 86-7).

21 Thomas, p. I89.

${ }^{22}$ Faulkner, 'Knights in the Magna Carta civil war', pp. I-8. Holt had already admitted that 'to travel south from the Border was to journey from the simple to the complex' (Holt, Northerners, p. 4I). Although he was really talking here about differences within 'the north', it certainly implied a question mark over the midlands and the south.

${ }^{23}$ Holt, Northerners, p. 5I.

${ }^{24}$ This wider debate is summarized and added to in Carpenter, 'Second century of English feudalism', pp. 30-7I. 
examples we already have, showing that some men followed their lords and that some did not. In general, the concentration in this article is on baronial tenants-in-chief. They were men of greatly varying importance, but it is unlikely that many of any significance have slipped entirely through the net of evidence, at least after the renewal of the struggle in October I2I5 when the sources become fuller. This gives us a fairly comprehensive view of this group. This article will try to provide a fairer assessment of the strength of the revolt, to give some of the reasons for that strength and to make some suggestions as to how the western revolt related, and in some ways contributed, to the final outcome of the crisis. It will discuss first south-western England and then the Welsh marches.

To cross south-western England westwards from the important royal castles of Corfe, Salisbury, Marlborough and Devizes was to travel from important centres of royal power to a rather remote periphery. $^{25}$ Although, since the death of Reginald earl of Cornwall in I I75, Cornwall had been part of the normal shire structure, for long periods before that it had been a virtually autonomous lordship. As we shall see, during the rebellion there were dangers that the county would again become such a lordship. Neither Cornwall nor Devon was visited by King John or the regent William Marshal during the conflict of I2 I5-I7. John only once briskly crossed eastern Somerset on his way from Gloucestershire to Dorset in I2I6; the regent did not visit Somerset at all. ${ }^{26}$ Somerset was also notable for an absence of royal castles, although Bristol, held by the king, was close to northern Somerset and the prominent loyalists Peter des Roches, bishop of Winchester, and William Briwerre did have castles at Taunton and Bridgewater respectively. ${ }^{27}$

The five south-western counties contained their full share of the administrative and political classes of England. In Kathryn Faulkner's attempt to estimate the number of administrative knights in the different counties of England in the period II99-I2I6, 527 were located in the south-western counties and some 348 of these in Cornwall, Devon and Somerset. These figures compare with the I, I 86 located within J. C. Holt's

${ }^{25}$ For a summary list of castles, royal or otherwise, in this period, see R. A. Brown, 'A list of castles, I I54-I2 I6', Eng. Hist. Rev., lxxiv (1959), 249-80. Marlborough was the only one of these castles to be lost by King John, handed over to Prince Louis in June I2 I6 and regained by the regent in the spring of I2I7, during Louis's absence on the Continent (Painter, Reign of King John, p. 375; Carpenter, Minority of Henry III, pp. 27-8).

${ }^{26}$ King John actually landed at Dartmouth in Devon on his return from the Continent in I 2 I 4, but thereafter was never in the county. For his itinerary, see T. D. Hardy, 'Itinerarium Johannis Regis Angliae', Archaeologia, xxii (I829), I24-60. The regent's itinerary to the end of Sept. I2I7 can be roughly reconstructed from the patent rolls (Calendar of Patent Rolls, 121625, pp. I-97).

${ }_{27}$ Brown, pp. 263, 278; R. V. Turner, 'William Briwerre', in R. V. Turner, Men Raised from the Dust: Administrative Service and Upward Mobility in Angevin England (Philadelphia, Pa., I988), pp. 7I-90, at p. 80; N. Vincent, Peter des Roches: an Alien in English Politics, 1205-38 (Cambridge, I996), p. 62. 
broadest interpretation of the extent of the north, which included more than twice as many counties as the south-west. ${ }^{28}$

Of the two earls whose titles derived from counties of the southwestern region, one, William earl of Salisbury, was one of the more poorly endowed earls, even after he obtained most of the honour of Trowbridge around I2I4. ${ }^{29}$ The other, William de Redvers, earl of Devon, held the largest barony based in the region, although even his was hardly a lordship of the first rank. ${ }^{30}$ Moreover, by I2 I 5 he was an old man and not, it seems, very active. ${ }^{31}$ In terms of knight's fees in the south-western counties, both of these lordships were outshone by the more southerly dependencies of the huge honour of Gloucester. ${ }^{32}$ Only three other baronies in the region amounted individually to more than fifty knight's fees: those of Robert de Courtenay in Devon, and of Robert of Cardinham and Reginald de Vautorte in Cornwall. ${ }^{33}$

Table I (see below, p. 35) presents an analysis of baronial rebellion in southwestern England. ${ }^{34}$ For purposes of comparison, Table 2 (p. 37) provides a list of barons who are either known to have been loyal or for whom there is no evidence of rebellion. Together, they show that a substantial part of the baronage of the south-western counties of England, at least at one time or another, can be shown to have been in rebellion. If, with the exception of the honour of Gloucester, not shown in these tables, and of the earl of Salisbury in his relatively short period of rebellion, the

${ }^{28}$ K. Faulkner, 'The transformation of knighthood in early I 3 th-century England', Eng. Hist. Rev., cxi (I996), I-23, at p. 6. Although Holt forswears a definite geographical extent for 'the north', for this purpose of comparison it has been taken to include all the counties that he concerned himself with, i.e., Northumberland, Durham, Cumberland, Westmorland, Lancashire, Yorkshire, Cheshire, Staffordshire, Nottinghamshire, Derbyshire and Lincolnshire (Holt, Northerners, pp. I4-I6).

${ }^{29}$ B. W. Holden, 'The balance of patronage: King John and the earl of Salisbury', Haskins Society Jour., viii (I996), 79-89, at pp. 80, 87.

30 Although a I263 inquest reported I3 I knight's fees, the often much lower demands for scutage from the honour suggest either exchequer ignorance, favoured treatment or, perhaps relevant here, a lack of effective lordship on such a scale (T. K. Keefe, Feudal Assessments and the Political Community under Henry II and his Sons (Berkeley, Calif., I983), pp. 47, 259, n. I24; I. J. Sanders, English Baronies: a Study of their Origins and Descent 1086-1327 (Oxford, I960), p. I37).

${ }_{31}$ Rotuli Litterarum Patentium, ed. T. D. Hardy (Record Comm., I835), p. I88. See also Painter, Reign of King John, pp. 297, 359.

32 Around I 45 knight's fees of the honour of Gloucester were located in south-west England by the I2I I-I2 inquest, while the same source gives only 58 knight's fees in the Welsh marches (not counting Glamorgan), all in Gloucestershire. There were, of course, also many knight's fees outside both of the regions dealt with here (Red Book of the Exchequer, ed. H. Hall (I vol. in 3, Rolls ser., I896), ii. 607-Io (hereafter Red Book of the Exchequer)).

33 Note that the barony Totnes was divided and Reginald de Vautorte, who came of age in I2IS and had been a ward of Peter des Roches, bishop of Winchester, acquired half of it, considerably augmenting the lordship he had based on the barony of Trematon (Vincent, pp. 72-3, I I6).

34 In Tables I-4 (below, pp. 35-40), and elsewhere in the article, the author has used the baronies and probable baronies of Sanders, English Baronies as a rough and ready guide to baronial status, although he has listed separately those marcher lordships in Wales that are often combined in Sanders's classification, as well as some lordships in Wales not included at all by Sanders. 
greater barons tended not to be among the rebels, this does not seem to have been an effective discouragement to the rebellion of lesser barons. The rebellion was not confined to specific areas. Out of the five counties concerned, only in one - Cornwall - were there no baronial rebels, and even in this case the absence is misleading.

King John's sheriff in Cornwall at the start of I2 I 5 was John Fitz Richard, in control of Launceston castle and the royal demesne in Cornwall, made up of the remaining demesne of the old, forfeited honour of Mortain. John Fitz Richard held around seven knight's fees of the honour himself and, but for the persistence of the notion of that honour, might be considered of baronial or semi-baronial status in his own right. ${ }^{35}$ Despite King John's order, he resisted replacement as sheriff from 30 May I2I5 until after Magna Carta. After that he was replaced, probably by I7 September I2 I 5 . However, subsequently he was at least intermittently a rebel up until June I 2 I 7. In November I I 6 , though, he was apparently in the king's service and was ordered to hand over the castle of Lydford in Devon to William Briwerre. Whether he obeyed this order is unclear. ${ }^{36}$

At first sight, there seems no very obvious reason for John Fitz Richard's recalcitrance and rebellion, except for his loss of office. Some of his lands in Dorset and Somerset seem to have fallen into the hands of the king because of the rebellion of William de Montacute, who had held the lands as John Fitz Richard's custodian. ${ }^{37}$ Although it is not clear when this happened, it is suggestive of some of John Fitz Richard's connections and, as will be discussed below, others may have shared the objection to his dismissal as sheriff.

Another focus for trouble in Cornwall seems to have been the twenty knight's fees in that county of the honour of Ongar, the collection of lands that had been built up by Henry II's justiciar, Richard de Lucy. Of the men who held or had held land of this honour in Cornwall - William Briwerre, ${ }^{38}$ Robert of Cardinham, ${ }^{39}$ Robert Peverel, ${ }^{40}$ Robert Fitz

${ }^{35}$ Red Book of the Exchequer, ii. 456; Pipe Roll 16 John, p. Io6.

${ }^{36}$ Rot. Litt. Pat., pp. I42, I44, I55b; Rotuli Chartarum, ed. T. D. Hardy (Record Comm., I837), pp. 2I 8-2I8b; Rotuli Litterarum Clausarum, ed. T. D. Hardy (2 vols., I833-44), i. 243b, 244, 277, 3Iob; Patent Rolls 1216-25, pp. 5, 67. In I224, John Fitz Richard regained the sheriffdom, having already in I 220 taken a share in farming the stannery of Cornwall (Pat. Rolls $1216-25$, pp. 272, 432).

${ }^{37}$ Rot. Litt. Claus., i. 3 Iob.

38 William Briwerre had acquired an interest by helping to finance the claims of Richard de Lucy's granddaughter, Rohese (Painter, Reign of King John, pp. 75-6). In I2 I4 he answered in Cornwall for the scutage concerning the Poitou campaign due from two of the fees of the heir or heiress of Richard de Lucy (Pipe Roll 16 John, p. 63).

${ }^{39}$ Robert of Cardinham had custody of eight of the Lucy fees in Cornwall at the time of the Poitou scutage (Pipe Roll 16 John, p. 63).

${ }^{40}$ Robert Peverel had custody of the honour of Ongar in I2IO-II (Pipe Roll 13 John, pp. I30-I). In the period I2IO-I2, he held nine knight's fees of the Lucy honour, when Robert Fitz Walter, who was the grandson of Richard de Lucy, held the other I I (Red Book of the Exchequer, ii. 539). Robert Peverel had been a wide-ranging royal servant in King John's reign, holding many custodies, but he seems to have become a rebel by around June I2I6, returning to Henry III's allegiance in July I2I7 (Rot. Litt. Claus., i. 276b, 3I5b-3I6). 
Walter, ${ }^{41}$ Geoffrey de Lucy, the possibly illegitimate son of Richard de Lucy's eldest son Geoffrey, ${ }^{42}$ and Hugh de St. Philibert ${ }^{43}$ - only the first two remained loyal to the Plantagenets throughout.

As the examples of John Fitz Richard and of the holders of the Ongar lands in Cornwall indicate, men of power and influence in a county were not necessarily limited to the holders of baronies whose caput was in that county or even in that region, and while the more obscure rebels present difficulties, both in terms of their numbers and what we can find out about them, men who were not barons could be of considerable importance both individually and collectively.

In Devon, the rebellions in I2 I6 of William Paynel, William Fitz John and Henry de Pomeroy, brief in the latter case, would hardly contradict Painter's contention that it was a county fairly firmly under royalist control. ${ }^{44}$ However, one has also to deal here with the chronicle evidence and other material that tells a rather different story. In May I2 I 5, right at the beginning of the rebellion, when we have no evidence of any Devon baron in revolt, the new joint sheriffs of the county found themselves penned up and besieged in Exeter by rebels. It took two expeditions by royal forces, led by William earl of Salisbury and Robert de Béthune, and including Flemish troops, to raise the siege (admittedly, the first expedition took fright at the strength of the rebels when still in Dorset rather than in Devon). ${ }^{45}$ The threat in Devon did not disappear with the dispersal of the May I2 I 5 besiegers. In July I2 I6, Robert de Courteney was told that if he could not defend the city with the help of William Briwerre and the citizens of Exeter, he was to take William and all his men inside the castle. ${ }^{46}$ Devon was clearly not a safe place for loyalist sheriffs.

${ }^{41}$ Robert Fitz Walter lost his Lucy lands in Cornwall in 12 Io (Painter, Reign of King John, p. 76). However, he presumably regained them as part of the settlement with the church in I2I3, and on I4 May I2I5, the sheriff of Cornwall was notified that Robert's lands in the county had been given to Henry Fitz Count (Rot. Litt. Claus., i. 200).

${ }^{42}$ That Geoffrey had some of the Lucy inheritance in Cornwall is suggested by his appearance as a reversus in connection with that county, although also in connection with a variety of other counties and bailiwicks (Rot. Litt. Claus., i. 322b). For his descent, see The Complete Peerage, ed. G. E. Cockayne (I3 vols. in I4, I9I0-59), viii. 257-8.

${ }^{43}$ Hugh held nearly one and a half knight's fees of the honour of Ongar in Cornwall in I2II-I2, as well as a serjeanty worth 50 s in Bray in Berkshire (Red Book of the Exchequer, ii. 5 I4, 6I2). He was a reversus in Sept. I2I7 in Cornwall, Berkshire and Norfolk (Rot. Litt. Claus., i. $322 \mathrm{~b})$.

${ }^{44}$ Painter, Reign of King John, pp. 290, 359.

${ }^{45}$ Histoire des Ducs de Normandie et des Rois d'Angleterre, ed. F. Michel (Paris, I 840) (hereafter Histoire des Ducs de Normandie), pp. I47-9. See also Memoriale Fratris Walteri de Coventria, ed. W. Stubbs (2 vols., Rolls ser., I 872-3) (hereafter Walter of Coventry), ii. 220. Exeter was besieged again in Nov. I2I7, after the civil war had ended. This seems to have been a struggle between the ex-sheriff, Robert de Courtenay, shut up in the castle and prevented from coming to the exchequer, and Henry Fitz Count and Henry de Tracy (presumably Henry Fitz Oliver de Tracy of Barnstaple), acting on behalf of the new sheriff, William earl of Salisbury (Carpenter, Minority of Henry III, p. 66).

${ }^{46}$ Rot. Litt. Pat., p. 190. 
Two factors may help to explain this conundrum. As a backdrop to the local politics of Devon, it is important at least to be conscious of the Braose claims to Totnes and Barnstaple. Giles de Braose was awarded seisin of these, along with the rest of his father's lands, as part of his agreement with King John in October I2I5, although it is not clear how far these provisions had been carried out before Giles's death in November I 2 I $5 .{ }^{47}$ Certainly, after the war, Reginald de Braose prosecuted these claims and it is difficult to know whether or not the Braose family had supporters in Devon during the war. ${ }^{48}$ Devon is also a large county and many baronial honours, including those held by rebels based elsewhere, had lands and dependencies there. The tenants of the honour of Gloucester, for example, had considerable lands in Devon. ${ }^{49}$

In addition to the relatively numerous rebel barons of Somerset, one other man should certainly be mentioned. William de Montague can only be denied baronial status on the basis that almost eleven of his knight's fees, most of his lands, were held of the long-escheated honour of William count of Mortain. ${ }^{50}$ William de Montague was an early and prominent rebel in I2I5, listed as being at Stamford by Roger of Wendover and excommunicated by Innocent III. ${ }^{51}$ On I 3 May I 2 I 5 , the king seemed to believe that Peter de Maulay might have captured William, but if so, he was subsequently released. In September I 2 I 5 John was issuing safe conducts to William and other south-western rebels. Land that William had held was being granted away by the king in December I 2 I 5 and March I2 I $6 .^{52}$ In April/June I2 I7, he had apparently gone over

${ }^{4}$ Holt, Magna Carta, pp. 363-4; Rot. Litt. Claus., i. 232b, 237b, 238b, 239; Rot. Litt. Pat., pp. I $57 b$, I 59 , I $59 b$, I60.

${ }^{48}$ Carpenter, Minority of Henry III, p. 35; Painter, Reign of King John, pp. 4I-3; Sanders, English Baronies, pp. 89-90, I04-5. It is difficult, for instance, to fathom the reasons for the rebellion of Guido de Breteville. He was known to be against the king by Apr. I2 I6. He held five knight's fees of the honour of Totnes, although of the Nonant portion, claimed by the Braoses but held by the loyal Reginald de Vautorte. Guido also held of William de Redvers, earl of Devon (Rot Litt. Claus., i. 264b, 265; Red Book of the Exchequer, ii. 594). Painter mentions the possibility of Braose supporters in Devon (Painter, Reign of King John, p. 3 IO).

49 See below, pp. I4, 24, 27.

50 Pipe Roll 16 John, p. Ios. For the family and the complications of the barony, fee or honour of Montacute and its relationship to the honour of Mortain, see Complete Peerage, ix. 75-7. There seems to be an obscure connection between William de Montague and John de Montague of Chiselborough, whose lands were described as 'de Monte Acuto', indicating 'of the fee of Montague' (Red Book of the Exchequer, i. I69). Henry Lovel, William Fitz John of Harptree (Som.) and John Fitz Richard also seem to have had connections with the 'fee of Montague' (Red Book of the Exchequer, i. I25, 2I9; Pipe Roll 16 John, pp. Io5-6). William Fitz John of Harptree was in turn involved in the descent of the barony of Marshwood (Dors.), as was Henry de Tilly. A Walter de Tilly was a rebel in Somerset (Sanders, English Baronies, p. 64; Rot. Litt. Claus., i. 30ob).

${ }^{51}$ Matthaei Parisiensis, Monachi Sancti Albani, Chronica Majora, ed. H. R. Luard (7 vols., I872$83)$, ii. 585,643 . This edition of Matthew Paris contains the best text of Wendover. See also Painter, Reign of King John, pp. 289, 307-8, 3 Iо.

52 Rot. Litt. Pat., pp. I 35b, I 55; Rot. Litt. Claus., i. 244, 252b, 3 Iob. See above, for William's tenure of some of John Fitz Richard's land as his custodian. 
to Henry III, having obtained pledges for his faithful service, but he seems to have been dead by 29 June I 2 I $7 .{ }^{53}$

The honour of Gloucester provides a link between the two regions of this study. Although important in Gloucestershire and Wales, it also had a significant part to play in south-western England, particularly in Somerset, Devon and Dorset. When Painter wrote, he was doubtful as to the extent to which Geoffrey de Mandeville, earl of Essex, had possession of the honour of Gloucester, his wife Isabelle's lands. However, it now seems clear that, at the outbreak of the rebellion, the honour, including the attached honour of Glamorgan, was largely in Geoffrey's hands. ${ }^{54}$ There is no sign that Geoffrey de Mandeville visited the region during the rebellion and war, but that does not make the honour of Gloucester of no consequence.

A considerable number of notable tenants of the honour were rebels at some time. Although we are very ill-informed about lesser rebels in the period before the granting of Magna Carta, one of the few we do know about is Josce de Bayeux, who held four knight's fees of the earl of Gloucester. He certainly had lands in Somerset and perhaps also in Dorset, as well as in Gloucestershire, and he may have been in rebellion until July or September I 2 I $7 .{ }^{55}$ Other rebels or their families held fiefs of the honour of Gloucester in various south-western counties. These included Nicholas, William, Brian and Peter de la Mara (or de Mara); Henry de Glanville; Nicholas Pointz; Roger of Raymes; Roger de Vilers; and William and Hugh de Neville, the latter the king's chief forester and castellan of Marlborough. William Fitz John, the rebel baron of Great Torrington in Devon, was also a significant tenant of the honour of Gloucester. ${ }^{56}$ It is doubtful if Hugh de Neville's Gloucester connections were foremost in his abandonment of King John in the summer of I 2 I 6 as Prince Louis progressed across the southern counties, but this defection from the curial heart of John's regime had an importance in its own right, not least in the handing over of Marlborough castle. ${ }^{57}$

53 His land and heir were given in custody to Alan Basset (Rot. Litt. Claus., i. 3I3, 336).

54 Painter, Reign of King John, p. 289. But see Rot. Litt. Claus., i. 209b-2 Iob; Cheney, p. 3I9, n. 2. For Glamorgan, see Lloyd, ii. 648-9. Some of the rebel tenants of Glamorgan also had land in the south-western counties of Devon, Somerset and Dorset, as well as in Gloucestershire (Rot. Litt. Claus., i. 3 I2b, 3 I3, 32 Ib). It is noteworthy that the Welsh attacks of I2 Is seem to have left Glamorgan alone. Note also the reference to the king's enemies and their ships from Cardiff in May I2 I6 (Rot. Litt. Claus., i. 27I).

55 Rot. Litt. Pat., p. 20ob; Red Book of the Exchequer, ii. 608. For possibly miswritten entries relating to him, see also Rot. Litt. Claus., i. 3 I4, $32 \mathrm{Ib}$.

56 Rot. Litt. Claus., i. 243, 264b, 300, 30ob, 30I, 302, 3 I7b, 33 I, 332, 339b, 340. A Roger Waspail held in I2II-I2 five knight's fees of the honour of Gloucester in Dorset, Somerset or Wiltshire; an Osbert Waspail was a reversus in Gloucestershire (Red Book of the Exchequer, ii. 607-9). Nicholas Pointz was later steward of Gilbert of Clare, earl of Hertford and Gloucester (Complete Peerage, x. 67I).

57 Histoire des Ducs de Normandie, pp. I74-5. 
The rebellion in south-western England was therefore both substantial and sustained. However, Painter's contention, that in determining the shape and extent of the rebellion as a whole 'the dominant factor was the attitude of the great barons', seems hardly appropriate here. ${ }^{58}$ That the lord of the honour of Gloucester was a rebel is clearly of some significance, although Geoffrey de Mandeville seems throughout to have been in the east of the country or in London, and his death in March I 2 I6 seems not to have weakened the rebellion in south-west England or in the Welsh marches. One might also think that his brief tenure of the honour was not likely to have generated much honorial loyalty to him personally. On the other hand, he held the lands by right of his wife, Isabelle, who was not accounted a reversa until September I217, and she may have inspired more loyalty among the tenants of the honour.

Henry de Bohun, earl of Hereford, might be allowed some role in the rebellion in Wiltshire, although as in the case of Geoffrey de Mandeville, there is no evidence of his personal presence in south-western England or in the Welsh marches, even though these were the principal regions in which he held or claimed lands. Henry's rebellion is perhaps one of the more easily explicable, much disturbed as he presumably was by the loss of his Wiltshire honour of Trowbridge after I2 I2, the honour being acquired by William earl of Salisbury around I $214 .{ }^{59}$ If royal instructions were followed, Henry ought to have regained the honour by 2 I June I 2 I 5 and the castle by 28 June I 2 I 5 , although to what extent these orders were effective and for how long, given the resumption of the war in the autumn of $12 \mathrm{I} 5$, is not clear. ${ }^{60}$

William earl of Salisbury was a major addition to the rebel ranks in the south-west, even if only for the nine months or so between the summer of I2I6 and early March I2I7. The earl may have had a very personal grievance in the supposed seduction of his wife by John. Judging by his later demanding stance with regard to the regency government, William may also have felt simply that he had been insufficiently rewarded for his stalwart services to his half-brother, the king. Others may have joined or later left the rebellion on the earl's account, although tenurial loyalties

58 Painter, Reign of King John, p. 290.

59 Henry de Bohun is not often easy to locate with certainty during the rebellion and civil war. While he did not have any significant lands outside the west, he was still captured at the battle of Lincoln (Chronica Majora, iii. 22; The Historical Works of Gervase of Canterbury, ed. W. Stubbs (2 vols., Rolls ser., I 879-80) (hereafter Gervase of Canterbury), ii. I I I). For the history of the Trowbridge dispute between Henry de Bohun and William earl of Salisbury, see Holden, 'Balance of patronage', p. 87; Sanders, English Baronies, p. 9I; Painter, Reign of King John, pp. 40, 210, 262-3, 330; Holt, Magna Carta, pp. 207, 360; Carpenter, Minority of Henry III, pp. 27, 30, I95. Although Henry seems to have lost control of the honour of Trowbridge before the beginning of the rebellion, a writ of the king in May I2 I 5 granting Henry's lands and chattels of that honour in Berkshire to William earl of Salisbury seems to anticipate resistance in parts of it at least (Rot. Litt. Claus., i. I I sb).

${ }^{60}$ Rot. Litt. Claus., i. 2 I 5; Holt, Magna Carta, p. 207. 
may not have been foremost here. The summer of I2I6 was the period of Prince Louis's greatest successes in southern England and Earl William's rebellion was probably, in part, governed by the immediate threat to his lands from that source. This may also have applied to many of his tenants and neighbours. ${ }^{61}$

Below the level of rebel earls, there was plenty of room for the dissatisfaction of individuals. Throughout the country, John exerted a growing financial pressure from $\mathrm{I} 203$ onwards, pressure that became greater still by 1207 and most intense in the years I2IO-I2. Both royal cash revenues and debts to the crown were rising significantly. ${ }^{62}$ It is, however, problematic to identify payments and debts to the king as causes of particular resentment. They were, in a sense, just part of the political game - albeit a game that was becoming rougher and more dangerous in the course of John's reign. For example, the rebel Robert de Mandeville in Dorset had been made to fine quite heavily -800 marks and eight palfreys - for the barony of Marshwood. He no doubt regarded the honour as his rightful inheritance, but the descent was complicated and disputed. It was a case where the king might be expected to demand more than usual for a favourable decision, and whether Robert felt aggrieved about the amount he was called upon to pay is not clear. ${ }^{63}$ Other rebels, too, such as William Malet and William de Montague, could have been resentful of their financial treatment by John, but as this article will show, there may have been more to their revolt than this.

Beyond individual dissatisfaction and grievance, there were signs of a more systemic problem affecting relations between the local community and the king in the south-west. In I2O3-4 the men of Devon fined for 5,000 marks to disafforest parts of the county, I,Ooo marks to be paid per annum over five years. ${ }^{64}$ This does not, however, seem to have solved their problems with the royal forest. In I208-9 the men of Devon are found owing 300 marks and a palfrey, apparently for a fine to prevent Hugh de Neville from carrying out a regard and perambulation in the royal forest. ${ }^{65}$

In I2O3-4 the men of Cornwall arranged an elaborate fine for 2,200 marks that the county might be disafforested and that they might have a

${ }^{61}$ Holden, 'Balance of patronage', pp. 79-89; Painter, William Marshal, pp. 207, 2I2; Carpenter, Minority of Henry III, pp. 27, 30-I, 55

${ }^{62}$ There was some relaxation of this pressure by I2I4 (N. Barratt, 'The revenue of King John', Eng. Hist. Rev., cxi (I996), 835-55, at pp. 839, 84I, 845. It would be rather problematic to break down Barratt's estimates by geographical region. A breakdown of revenue for which the county of source was clear from the pipe rolls would be possible, with a great deal of work, but this is not the case for all revenue.

${ }^{63}$ Pipe Roll 8 John, p. I35; Sanders, English Baronies, p. 64. The barony answered for around I 5 knight's fees. For the continuing dispute over the inheritance, see Curia Regis Rolls, viii. $23-4$.

${ }^{64}$ The bishop of Exeter, the earl of Devon and perhaps others were not, at least initially, included in this fine, but were allowed the possibility of arranging their inclusion with the men of Devon who had negotiated the fine (Pipe Roll 6 John, p. 85).

65 Pipe Roll 11 John, p. 92. 
sheriff from among their own people, whose power would at the same time be restricted. Even if this sheriff were to prove unsatisfactory to the king, another was then to be appointed who did not hate them and who would treat them well. The sheriff before this fine was made had been William Briwerre, of whom more will be said below. ${ }^{66}$ In spite of this fine, the men of Cornwall had to fine again in I207-8 to remit the king's ill will and to have a sheriff from among their number residing in the county, perhaps a response to having Geoffrey de Neville, the king's chamberlain, placed over them. It was subsequent to this that John Fitz Richard, who would have been accounted a local man, was appointed sheriff (William de Boterell, another local man, took up the office after the first fine). ${ }^{67}$ In April I2I5 it was still apparently necessary to try to conciliate the men of Cornwall by issuing a charter granting privileges relating to the forest, the stanneries, the sheriffdom, the taxation of the fees of the honour of Mortain and runaway villeins. ${ }^{68}$

We know little about the instigators of these arrangements in Devon and Cornwall, but in the counties of Dorset and Somerset the sources are more revealing. In I209-Io the men of Dorset and Somerset fined for I,200 marks to be quit of the IoO mark increment on the farm of the counties and to have a sheriff from their own ranks, resident in the shires, explicitly excluding William Briwerre and his associates. ${ }^{69}$ William Briwerre had been sheriff from December I207 to Christmas I209. He was then replaced with William Malet who was subsequently revealed as the leader of those negotiating the fine. ${ }^{70}$

In I2I2, it became apparent that there were serious problems over this fine. The king wrote to a named group of fourteen Dorset and Somerset landholders ordering them to come to the exchequer to answer for themselves and the other knights of Dorset and Somerset, because they had not kept to the fine they had made through William Malet for having a local man as sheriff. ${ }^{71}$ By Michaelmas I2 I2, 350 marks of the original fine remained unpaid, but there was evidently a dispute. William Malet had, it seemed, promised 200 marks more than the men of the counties had agreed to, as well as promising, without authorization, firoo to

${ }^{66}$ Pipe Roll 6 John, p. 40; List of Sheriffs for England and Wales from the Earliest Times to A.D. 1831 (I 898) (hereafter List of Sheriffs), p. 21. Attempts to limit the royal forest in localities were not new nor were they restricted to any particular area of the country (see, e.g., Pipe Roll 2 Richard I, pp. 67, I45, I55 (Yorks., Beds., Surrey); Pipe Roll 6 John, pp. 32, I89 (Essex, Yorks.); Pipe Roll 9 John, p. 66 (Surrey)). For attempts elsewhere to influence the choice of sheriff, see Holt, Northerners, pp. 74, I56 (Lancs. and Lincs.); The Memoranda Roll for the Michaelmas Term of the First Year of the Reign of King John, 1199-1200 (Pipe Roll Soc., new ser., xxi, I943), p. xcvii (London).

${ }^{67}$ List of Sheriffs, p. 2I; Pipe Roll 10 John, p. I83.

${ }^{68}$ Rot. Chart., pp. 206-206b.

69 Pipe Roll 12 John, p. 75.

${ }^{70}$ List of Sheriffs, p. I 22.

71 Rot. Litt. Claus., i. I3 I. 
William Briwerre, no doubt as a sweetener for these arrangements. These amounts were charged to William Malet individually. The arrears of the increment of Ioo marks on the farm of the shires were also charged to him as sheriff because the fine had not been paid. ${ }^{72}$ In November I2 I2, William Malet was replaced as sheriff with the curialis Richard de Marisco and by I2I3-I4, William Malet owed 2,000 marks in respect of his period as sheriff. ${ }^{73}$

If William Malet may not have been blameless here, the affair certainly seems to have worked to the king's disadvantage. Not only did William Malet assume a prominent role in the rebellion of I2 I 5 , excommunicated by Innocent III and becoming one the twenty-five barons of Magna Carta, but of the fourteen men of Dorset and Somerset called to the exchequer in I2I2, William de Montague, Eudo Martell, William de Cahaignes, William Paynel, Alured of Lincoln, Robert de Newburgh and William Dacus became rebels, as did possible heirs or relatives of three more: Robert Belet, William de Mariscis and Gerard of Brocton. ${ }^{74}$ This was a revolt of the leaders of county society. ${ }^{75}$

The reasons why someone like William Briwerre was viewed with such hostility in the south-west are fairly familiar. An aggressive administrator, a man who could bully, who could attract and extract bribes, a man with special access to the king's ear and favour: from humble origins, William made himself a figure to be reckoned with in all the lands from Winchester westwards and indeed almost anywhere in the country. ${ }^{76}$ Yet William Briwerre was not all that south-western England had had to face. William de Harcourt, a household steward and paymaster, had been sheriff of Somerset and Dorset from January I 2 I 4 to April I2 I 5. He was succeeded first by Ralph of Bray, one of the king's marshals and formerly in the household of William Briwerre, and then from June I2 I6 by Peter de Maulay, one of King John's principal alien

${ }^{72}$ Pipe Roll 14 John, p. I I6.

${ }^{73}$ List of Sheriffs, p. I22; Pipe Roll 16 John, p. Ioo.

${ }^{74}$ Holt, Magna Carta, p. 478; Roger de Wendover . . . Flores Historiarum, ed. H. G. Hewlett (3 vols., Rolls ser., I886-9), ii. I I4, I69; Rot. Litt. Claus., i. 26rb, 300b, 301, 302, 303, 306b, 307b, 319, 323b. Of the Twenty-Five barons of Magna Carta, four had substantial interests in south-western England - Geoffrey de Mandeville, Henry de Bohun, William Malet and Robert Fitz Walter, although in the latter case his lands in Cornwall were perhaps of relatively minor concern to him. Only the first two of these men had important interests in the Welsh marches, although there one might add another member of the Twenty-Five, William Marshal junior, in view of his future prospects.

${ }^{75}$ Like William de Cahaignes and Robert Belet, William de Montague was a former sheriff of Dorset and Somerset (I204-7). He had ended his tenure of the sheriffdom in substantial arrears, in bad odour with the king and with disputes over the increment, being replaced by William Briwerre (List of Sheriffs, p. I22; Rot. Litt. Claus., i. 97b, I I2).

${ }^{76}$ For a study of William Briwerre's career, see Turner, 'William Briwerre', pp. 7I-90. Turner saw the behaviour of William Briwerre as representative of the sources of baronial complaint in I2 I5 (Turner, 'William Briwerre', p. 89). See also Painter, Reign of King John, pp. $7 \mathrm{I}-8$. 
servants. From I209 until May I2 I 5, Robert de Vieuxpont, another man closely associated with John as a familiaris, had been sheriff of Devon and he had been preceded by William Briwerre. ${ }^{77}$ Here, as in the north, there could be a feeling that the country was being exploited by a clique made up of the familia regis. ${ }^{78}$

As elsewhere, by the time of the rebellion, King John seems to have been in conciliatory mood in the south-west. On I3 May I2I5, he appointed Henry de Pomeroy, a household knight but also an established Devon baron, along with John of Earley, William Marshal's man, as jointsheriffs of Devon. Although they seem soon to have been replaced by Robert de Courteney, he ought to have been an equally appropriate, baronial choice. ${ }^{79}$ And although the attempted replacement of John Fitz Richard as sheriff in Cornwall seems to have backfired, his successor, Robert of Cardinham, was at least a local baron rather than a familiaris. ${ }^{80}$ Wiltshire was already in the hands of a baron, albeit King John's halfbrother William earl of Salisbury. In Somerset and Dorset there was no relaxation of the curial grip. ${ }^{81}$

On I7 September I2I5 King John went further in Cornwall, committing the county to Henry Fitz Count, the illegitimate son of Reginald earl of Cornwall (d. II77), and ordering an inquisition as to whether he should hold it hereditarily. ${ }^{82}$ In one sense, this was a late example of John's attempts to satisfy outstanding claims after the Runnymede settlement, although most examples involved the rebels of I2I5 rather than loyalists. ${ }^{83}$ There must have been the hope that this potentially major concession would secure the loyalty of Cornwall. However, by I6 November I2 I5, Henry Fitz Count's behaviour must have confirmed any royal doubts that there had been about this move. The sheriffdom was taken from him and committed again to Robert of Cardinham. In the letter to the county, the king made it known that 'it was not through us that Henry Fitz Count took fidelities and homages of our demesnes'. ${ }^{84}$ Henry's father, Reginald earl of Cornwall, had not accounted at the exchequer for Cornwall and had, as far as we can tell, had lordship over all the landholders of the county. Henry had apparently been going against royal wishes in trying to recreate his father's position in the county, or, at the very least, in jumping the gun. Yet if King John

${ }^{77}$ List of Sheriffs, pp. 34, I22; S. D. Church, The Household Knights of King John (Cambridge, I999), pp. 9, II, I3, 33, 4I-2, 47, II I; Holt, Northerners, pp. 47, 220-2, 247. For Peter de Maulay's background and the political phenomenon of the 'aliens', see Vincent, pp. 26-7, 36-9.

${ }_{78}$ Holt, Northerners, p. 224.

79 Rot. Litt. Pat., p. I 36; List of Sheriffs, p. 34; Sanders, English Baronies, pp. 69-70.

${ }^{80}$ Sanders, English Baronies, p. I го.

${ }^{81}$ List of Sheriffs, pp. I22, I 52.

${ }^{82}$ Rot. Litt. Pat., p. I55b. For Henry Fitz Count's claim to Cornwall, see Complete Peerage, iii. 430 .

83 Warren, King John, pp. 24I-2.

${ }^{84}$ Rot. Litt. Pat., p. I 59 . 
would not stand for this, on 7 February I2I 7 the regency government felt the need to give way, granting Henry the county of Cornwall just as his father had held it, and assuring him that he would not be disseised of it 'except by the consideration and judgement of our court'. Letters followed the next day, attempting to protect certain lands of William Briwerre senior and junior. ${ }^{85}$ In November I 2 I7, letters had to be sent to try to protect Robert of Cardinham from Henry. ${ }^{86}$

It is worth asking how serious for John and his heir the revolt in southwestern England was. Certainly, the king had a very secure base in Dorset at Corfe, which no more came under threat throughout the whole struggle than did Nottingham. As we have seen, Exeter was in danger in the early days of the revolt, but in general it is clear that in south-western England, as elsewhere, the rebels alone did not have the offensive force to sweep King John or the regency away by force. The rebels indeed were, in general, under the greater pressure. They could be harried, distrained, even sometimes captured; ${ }^{87}$ loyalists could be offered their land. There was some strengthening of the revolt in the summer of I 2 I6, while it seems to have progressively, if gradually, weakened after the return to Henry III's allegiance of William earl of Salisbury in March I2I7. If, at least before that, there was what might be described as a stalemate, although in the king's favour, this situation was fragile.

Prince Louis and his French troops had the potential to change the balance dramatically. Loyalty for barons in the south-west was a reasonably safe option unless Louis threatened their lands. However, if the rebels - west, east, south or north - could not face King John's main household forces, neither John nor the regent ventured to oppose Prince Louis and his troops; not until, that is, the regent had the chance to catch only a portion of them at Lincoln. After Louis had taken Winchester, Farnham and Odiham in Hampshire, John's position seemed far from secure. When Louis advanced, there was a clear danger that loyal barons would despair of Plantagenet prospects and switch sides. The safety of major royal castles depended on the loyalty of the men who held them. The surrender of Marlborough to the knights of Robert de Dreux in June I 2 I6 by the curialis Hugh de Neville, following on the defection of William earl of Salisbury, along with the earls of Arundel and Warenne, sent a shock wave westwards through southern England. Soon after, John seemed to be concerned about the safety of Salisbury castle and similarly, in July I216, about the security of Devizes. ${ }^{88}$ Also in June I216, the aged William de Redvers, earl of Devon, seems to have been given permission

85 Pat. Rolls 1216-25, p. 30; Rot. Litt. Claus., i. $297 \mathrm{~b}$.

${ }^{86}$ Rot. Litt. Pat., p. $34 \mathrm{Ob}$. When Henry finally resigned the county in $\mathrm{I} 220$ to go on crusade, Robert of Cardinham again became sheriff (Complete Peerage, iii. 430; List of Sheriffs, p. 2I).

87 See above for William de Montague and Thomas and 'Wygara' de Mara. See the notes to Table I (below, p. 35) for Henry de Bohun and Robert de Mandeville.

88 Rot. Litt. Pat., pp. I87b- I88, I9ib. 
to submit to or at least to buy off Louis, providing that William's son Baldwin, still a minor, remained in the king's service, a telling sign of the seriousness of the situation by that time. ${ }^{89}$

The crisis of the summer of I2I6 passed, and although the French troops never did venture further west than Wiltshire, there was nothing preordained about this. Although Louis lost Marlborough, Winchester, Odiham and Farnham during his absence in France from 27 February to 23 April I2 I7, he then proceeded to retake Farnham and Winchester. His caution and understandable concern to deal first with Dover and Windsor seem to have prevented him from marching to confront in the west either John in 1216 or the regent in I2 I7. A bolder, although more risky, policy might well have paid dividends in either case. ${ }^{90}$

Victory for the regency government in I2I7 came at a price for royal authority in the south-west. The re-issues of a modified Magna Carta in November I2I6 and November I217, along with the Charter of the Forest at the latter date, with their restrictions on the operation of royal lordship and the activities of royal officials, answered some, although not all, of the problems of south-western landholders. They would presumably have preferred that the I2I5 Magna Carta's ban on increments to the county farms had survived into the new charters. ${ }^{91}$ More specifically, Cornwall was no longer accounting at the exchequer. Henry Fitz Count was trying to impose his lordship on the whole county and even tried to exclude royal justices. ${ }^{92}$

The return of William earl of Salisbury to Henry III's allegiance was accompanied by his re-establishment as sheriff of Wiltshire and castellan of Salisbury, perhaps by hereditary right. ${ }^{93}$ Moreover, William was granted the castle of Sherborne and, most notably, the counties of Somerset and Devon, for his homage and service, 'salvo regali nostro', with instructions to the men of the counties to swear fidelity and perform homage to him, 'salva fide domini regis'. They were to answer to him 'tanquam domino suo'. The regency government clearly feared that if these grants were not put into effect, William would again join Prince Louis. ${ }^{94}$

In the event, William did account for Wiltshire in the exchequer year I 2I7-I 8 , although he paid no cash into the treasury from the farm. ${ }^{95}$ Resistance from Peter de Maulay and Robert de Courtney in Somerset and Devon also prevented the creation of what might almost have amounted to an appanage for Earl William, even though he seems to have

89 Rot. Litt. Pat., p. I 88.

${ }^{90}$ For general accounts of the war in Hampshire and Wiltshire in I2I6 and I2I7, see Painter, Reign of King John, pp. 374-5; Carpenter, Minority of Henry III, pp. 27-3I.

91 Clause 25 in Magna Carta I2 I5 (Holt, Magna Carta, pp. 456-7). For Magna Carta I2I6 and I2I7 and the Charter of the Forest, see Holt, Magna Carta, pp. 5OI-I 7.

92 Pat. Rolls 1216-25, pp. 202-3.

93 Carpenter, Minority of Henry III, p. 3 I.

${ }^{94}$ Pat. Rolls 1216-25, pp. 38, 86-7.

95 Pipe Roll 2 Henry III, pp. 6-7. 
received assistance in Devon from Henry Fitz Count and Henry de Tracy. By besieging Robert de Courteney in Exeter, they prevented Robert's coming to the exchequer in November I2I7. Earl William and the regency government had to turn elsewhere for the reward for his loyalty. ${ }^{96}$ Peter de Maulay hung on at Corfe until the end of May I22 I, gave up the sheriffdoms of Somerset and Dorset in favour of his undersheriff in November I22I, and lost Sherborne castle and the forests of Somerset and Dorset in January I222. ${ }^{97}$

These troubles turned out better than they might have done for the regency government. However, it would still be true to say that, if the strength of the rebellion in the south-west was, as argued here, caused by individual and collective dissatisfaction at the pressure of John's government and at the curial clique that had operated it at a local level for the government's and their own benefit, it could be said that it at least partially succeeded, and at relatively little cost to the rebels. There was no long toll of released captives in the south-west struggling with ransoms. Also, one might say that loyalists like Henry Fitz Count, Robert of Cardinham, Robert de Courtney and William earl of Salisbury (loyal for most of the time) were not, to say the least, unequivocally on the side of the government in a struggle with local society. They, just as much as the rebels, helped to set limits to the Plantagenet centralization that had come to a head in John's reign.

Let us turn now to the Welsh marches. From soon after the Norman Conquest, the area of the Welsh frontier and beyond had always presented the English crown with a double problem: the Welsh princes and the marcher lordships. These lordships were, in part, a means of keeping the Welsh in check, but their military strength, their special legal status and their semi-autonomous dealings with the Welsh and each other made them a potential threat to the king. ${ }^{98}$ The events of the period I207-I I had allowed King John to exercise unprecedented power in the Welsh marches. ${ }^{99}$ Through his servants, John held more castles in the area than any previous king. This remained true at the outbreak of the rebellion in I2 I5, even though there had been some royal concessions to barons from I2I 2 onwards. ${ }^{100}$ The two most important royal strongholds were Bristol in Gloucestershire, which had effectively been separated from the honour of Gloucester since John's own rebellion against Richard I, and Bridgenorth in Shropshire. Only in the northern march, where the earl of Chester held sway, was the king not directly interested.

${ }^{96}$ Carpenter, Minority of Henry III, pp. 66, 7I.

97 Carpenter, Minority of Henry III, pp. 250, 273-5.

98 It was the Magna Carta of I2 I5 that first formally recognized the existence of a 'Law of the March' (Clause 56 of Magna Carta, in Holt, Magna Carta, p. 468).

${ }^{99}$ For these events, see below.

100 Brown, pp. 260-80. 
The importance of the Welsh marches to the crown was reflected during the conflict of I2I5-I7 by John's visits to the area and by the regent's activities. Even before the conflict broke out, in December I2 I4, when the coming storm was already on the horizon, John made a tour through Gloucestershire, Herefordshire and Worcestershire, visiting Gloucestershire again briefly in February I2 I5. In late July and early August I2I5, during the lull that followed Magna Carta, John made a quick progress from Gloucestershire up to Bridgenorth in Shropshire and back via Worcester. In I2 I6, from I9 July to 21 August, he made an extended campaign through the area, from Bristol as far north as Whitchurch in Shropshire. After John's death, the young Henry III was crowned at Gloucester and the regent used Bristol and Gloucester as his principal bases. ${ }^{101}$ The Welsh marches were therefore of much greater concern to both King John and the regent than the south-west beyond Wiltshire and Dorset.

At first glance, Faulkner's estimates of the numbers of administrative knights in I I99-I2I6 for the five English counties of the Welsh marches would, at 385 , seem to suggest a proportionally rather small politically and administratively active class. ${ }^{102}$ However, one should in this region allow for a rather lesser incidence of the royal procedures that allow us to see these administrative knights, and for the probability of rather more than the usual level of military activity by the knightly class, given the circumstances of the marches. It also has to be emphasized that Faulkner's figures do not include any of the lands in Wales. Regarding the size of the knightly political community, the north, even generously interpreted, cannot be said to overshadow south-western England and the Welsh marches added together.

Of the earls whose titles derived from the region of the Welsh marches, Henry de Bohun, earl of Hereford, at the outbreak of the rebellion was very much the poor relation of the comital class, especially after he had lost the honour of Trowbridge to the earl of Salisbury. Ranulf earl of Chester, on the other hand, possessed one of the greatest honours both in the region and in the kingdom as a whole. Still greater though, was the honour possessed by Geoffrey de Mandeville. Although earl of Essex and not accorded the title earl of Gloucester, his wife was certainly the countess of Gloucester and, as we have seen, from I2I4 had possession of at least most of the honour. Of other baronies in the region, only three had lordship over more than fifty knight's fees: William Marshal's honour based at Chepstow; Ralph de Somery's at Dudley in Worcestershire; and Walter de Lacy's at Weobley in Herefordshire. However, it is also

\footnotetext{
101 Hardy, 'Itinerarium Johannis regis', pp. I55, I 57, I 59; Pat. Rolls 1216-25, pp. I-97.

${ }^{102}$ Faulkner, 'Transformation of knighthood', p. 6. Faulkner warns of the danger of underestimates in peripheral areas of the kingdom, although she tries to compensate for this, and she resorts to guesswork for Cheshire (Faulkner, 'Transformation of knighthood', p. II).
} 
important to note that the baronies and marcher lordships that had been taken in I208 from William de Braose (d. I2I I) amounted to some I30 knight's fees and much of this power would be reconstituted by Giles and Reginald de Braose during the I2 I 5-I 7 conflict. ${ }^{103}$

Table 3 (see below, p. 38) lists the rebel barons in the Welsh marches, together with details of their rebellions and returns to loyalty. Table 4 (see below, p. 40) lists barons known to be loyal, or at least not known to have rebelled. If the list of loyal barons is somewhat longer than in the south-west, the number and proportion of rebel barons is still much greater than one would expect from some historians' assessment of the strength of loyalty in the area. ${ }^{104}$

Of the English counties included here in the Welsh marches, only in Cheshire were there no baronial rebels. Of course, as Ranulf earl of Chester was loyal and the only baron of the king based in the county, this was necessarily so. It may well also have been true that there was 'not a single example of a rebel holding land of the earl of Chester infra Limam except where, as in the case of the Constable, John de Lacy, he also held baronies or important mesne tenures elsewhere'. The earl had, as Holt pointed out, issued a charter of liberties for Cheshire apparently of his own free will and perhaps this or the earl's power quelled any inclination to rebel. ${ }^{105}$ However, it is difficult to see which sources would tell us if there were rebels in Cheshire, if land there constituted their only holdings. The earl's charter of liberties would suggest at least some pressure from below in I2I5.

Although rebel barons must take up most of our attention, again we cannot ignore men of lesser status. The tenants of the honour of Gloucester provide one of the clearest links between south-western England and the Welsh marches. Some tenant rebels who had lands in the south-west also had lands in the Welsh marches, and there were other tenant rebels there as well. Of the de la Mara (or de Mara) clan of Gloucester tenants, Peter de Mara held land in Herefordshire, as well as in Wiltshire and the honour of Wallingford. ${ }^{106}$ Thomas de la Mara, perhaps the most important of them, held ten knight's fees in Gloucestershire of the honour, although he held land of the loyalist Walter de Lacy as well. ${ }^{107}$ The rebel Gloucester tenant Nicholas Pointz held more than seven knight's fees of the honour and had land primarily in Gloucestershire as well as in Dorset and Somerset. Osbert Waspail seems to have been a tenant in both Gloucestershire and the south-west, and

103 See below, pp. ooo.

104 See, e.g., Painter, Reign of King John, p. 290; Carpenter, Minority of Henry III, p. 20.

${ }^{105}$ Holt, Northerners, p. 44. For the charter, see The Charters of the Anglo-Norman Earls of Chester, c.1071-1237, ed. G. Barraclough (Record Soc. of Lancashire and Cheshire, cxxvi, I988), pp. $388-92$.

106 Rot. Litt. Claus., i. 243, 298.

107 Red Book of the Exchequer, ii. 607; Rot. Litt. Claus., i. 282. Two of the de Mara family Thomas and a 'Wygara' - were in the king's prison in Bristol by 2I Aug. I2I6, perhaps captured at Worcester in early Aug. (Rot. Litt. Pat., p. I94b). 
William of Cardiff held one knight's fee of the honour in Gloucestershire. ${ }^{108}$ Important tenants of the honour of Glamorgan - Raymond de Sully, Herbert de St. Quintin, Robert le Sor, Henry de Umfraville and Gilbert de Turbeville - were also among the rebels. These also generally had lands in Gloucestershire, the south-western counties or both. ${ }^{109}$ Outside Glamorgan, where there is no evidence of any royal or loyalist activity, it is difficult to know how effective the resistance of these Gloucester tenant rebels was. In December I I 5, Geoffrey de Mandeville's men were still apparently holding the castle of Hanley in Worcestershire against the king when it was granted to the loyalist Roger de Clifford junior, 'if he could take it'. ${ }^{110}$

In the early part of I2I 6 , or very late I2I5 at the earliest, a letter from Walter de Clifford junior to King John reported on the situation in Herefordshire, past and present. He wrote that the whole county of Hereford, apart from the barons and their commilitones, had been with Giles de Braose, the rebel bishop of Hereford, against the king. However, after the bishop had come to the king's peace in October I2 I5, all had been loyal except three named knights - Walter of Stokes, Robert de Evereus and Richard Tirel - who were with Reginald de Braose. Walter de Clifford junior also wrote of the imminent threat from the Welsh when the current truce was due to end on I8 April I2 I6 and asked for the return of his own barons who were then with the king, so as to be able to offer resistance. ${ }^{111}$

This document has been used to support the argument that tenants followed their lords in rebellion or loyalty, although it does not really sustain such an interpretation. ${ }^{112}$ Whatever the precise meaning of commilitones, it says surely both more and less than the 'tenants' of the barons. Likewise, 'the whole county, excepting the barons and their commilitones', can hardly be read as the tenants of Giles de Braose. The letter surely does say something about the solidarities of the Herefordshire community, but these cannot be reduced to honorial solidarities.

In Shropshire, two men of note rebelled, apart from the rebel barons. Bartholomew Turet, lord of the Morton castle that passed to the Corbets in the twelve-thirties, was a rebel reseised of lands in Shropshire, Cornwall, Leicestershire, Oxfordshire and Yorkshire at the end of the civil

${ }^{108}$ Rot. Litt. Claus., i. 28ob, 282, 302; Red Book of the Exchequer, ii. 607-8.

109 Sully (Som.); St. Quintin (Glos. and Devon); Le Sor (Glos., Som. and Warwicks.); Umfraville (Devon); and Turbeville (Glos. and Dorset) (Lloyd, ii. 648-9; Rot. Litt. Claus., i. 3 I2b, 3І3, 32 Ib).

${ }^{110}$ Rot. Litt. Pat., p. I62.

111 Calendar of Ancient Correspondence Concerning Wales, ed. J. G. Edwards (Cardiff, I935) (hereafter Cal. Anc. Corresp. Wales), p. I. For Walter of Stokes, see Table 3 (below, p. 38). Robert de Evereus held just over one and a third knight's fees of the honor of Brecon and was presumably a member of the family of the later William de Evereys who married one of the Mortimer heiresses in the I4th century; a Walter Tyrel held a third of a knight's fee of the honor of Brecon (Red Book of the Exchequer, ii. 60I-2; Sanders, English Baronies, p. 75).

${ }^{112}$ Holt, Northerners, pp. 35-6. 
war. ${ }^{113}$ That figure of later legend, the evidently colourful Fulk Fitz Warin, lord of Whittington, was prominent enough to be noticed by Roger of Wendover and Innocent III. ${ }^{114}$ In September I2 I7, he was still Henry III's manifestus inimicus, although he must have come to terms soon afterwards. ${ }^{115}$

Painter's argument that, as an explanation of the prevalence of rebellion in any particular area, the individual decisions of the great barons were the biggest factor, would seem to work rather better in terms of the Welsh marches than in the south-west. ${ }^{116}$ We might allow Geoffrey de Mandeville and his wife, as lord and lady of the honours of Gloucester and Glamorgan, and Henry de Bohun, earl of Hereford, as lord of the Gwent-Gloucestershire honour of Caldicot, to be among those 'great barons'. ${ }^{117}$ However, when we turn to other rebel 'great barons' of the region, some questions emerge about the nature of the leadership of such men.

Giles de Braose, and subsequently Reginald de Braose, might be regarded as of the highest status, but at the beginning of the rebellion, they were not in possession of the Braose lands, with the exception of the land of Giles's bishopric of Hereford. Giles had his own very special status, too, that does not perhaps deserve Painter's dismissal of him as 'a wild marcher lord covered with clerical vestments'. ${ }^{118}$ As the only rebel bishop associated with 'the Army of God and the Holy Church', his episcopal office was surely not without importance to the rebels.

The rebel John Fitz Alan was the brother and, at least by I2I7, the heir of William Fitz Alan (d. I2 I 5-I7), but again, at the outbreak of the rebellion, William Fitz Alan was a minor and the lands, and presumably William himself, were in the custody of Thomas of Erdinton. Osbert Fitz Alan, perhaps another brother or an uncle of the family, also rebelled in I 2 I 5. ${ }^{119}$ William Marshal junior, whose anticipated inheritance lay chiefly

113 Rot. Litt. Claus., i. 373b. Morton castle seems to have been in the hands of Thomas of Erdinton in May I215. Bartholomew was apparently a rebel before Magna Carta, as the lands of which he had been disseised were restored 2I June I2I5. His land in Yorkshire was granted to Engelran de Pratellis in Feb. I2 I6 and his land in Cornwall was given to Roger of Morton, possibly a relative, in June I2I6. Bartholomew was granted his scutage in Yorkshire and Shropshire around Nov. I2I7 (Rot. Litt. Claus., i. I99, 215, 248b, 274b, 372).

114 Chronica Majora, ii. 585, 643.

115 Rot. Litt. Claus., i. 32 I, 352, 376.

116 Painter, Reign of King John, p. 290.

117 In terms of lands, the honour of Caldicot could hardly qualify Henry de Bohun as a 'great baron', especially as for much of the time he was not in possession of the honour of Trowbridge in Wiltshire, but nevertheless he was an earl (Painter, Reign of King John, p. 2Io).

118 Painter, Reign of King John, pp. I 55, I72, I75, I78, 275.

119 Chronica Majora, ii. 585, 644. It is interesting that a clause in Thomas of Erdinton's fine for the land of William Fitz Alan (d. I2I3) and for the marriage of the heir, the eldest son, William Fitz Alan (d. I2 I 5-I7), to Thomas's daughter contained a provision for a younger son to marry Thomas's daughter, if the elder son died. If John Fitz Alan was that younger son, he at least seems not to have been in Thomas's custody or else he escaped. Otherwise, he could hardly rebel (Pipe Roll 16 John, p. I2I). Before Thomas of Erdinton's fine, the lands seem to have been held by John Marshal 'ut custos', as he accounts for the Poitou scutage of the honour (Pipe Roll 16 John, pp. I2I-2). 
in the region of the Welsh marches, was a rebel from the early stages to March I2I7. It would seem that he had considerable support, although unfortunately we cannot specify from where or from whom. He was named immediately after the earls and counts among the twenty-five barons of Magna Carta and credited with a contingent of knights equalled only by Geoffrey de Mandeville. At least in the summer of I2I6, he was active in the west when the rebels took control of Worcester. ${ }^{120}$ As merely the heir of William Marshal senior, his very high status among the rebels was not based on lands that he controlled or on the number of his tenants by knight-service, although one might expect at least part of his support to be based on the lands and lordships that he was due to inherit.

If the decisions to rebel made by major barons were more significant in the Welsh marches than in the south-west, their influence operated as much through status, history and claims, as through land, castles and lordship actually held by the leaders in May I2 I5. If men followed the Braoses, the Fitz Alans and William Marshal junior, it was not because of their 'feudal' power over tenants. Dispossessed lords, minors and the sons of great lords could not automatically expect support from the tenants of honours. It might rather be sympathy, community feeling and hopes of future reward, as well as of present excitement, and these feelings were not necessarily limited to tenants of the Braose, Fitz Alan and Marshal honours. It is not clear whether it was the Fitz Alan tenants, neighbours such as Fulk Fitz Warin, Bartholomew Turet and the Corbet family, the Welsh, or a combination of all of these who were instrumental in King John's apparent loss of control of Oswestry before August I2I6. More clearly, it is unlikely that, even with strong Welsh support, the Braoses could have captured all the castles of their lordships in Wales without the assistance or acquiescence of the tenants of their former Welsh lordships. ${ }^{121}$

As in the south-west, individual grievances played a part in stoking the rebellion in the Welsh marches. When, on Io May I2 I5, King John tried making concessions to individuals in an attempt to ward off the revolt, it was to Geoffrey de Mandeville, concerning his fine for the honour of Gloucester, and to Giles de Braose, concerning his fine for his father's lands - both 'western' grievances - that John offered the judgement of his court. ${ }^{122}$

${ }^{120}$ Chronica Majora, ii. 585, 643; Rot. Litt. Claus., i. 299. William Marshal junior's quota was set as 200 knights (Holt, Magna Carta, p. 479). For the rebel capture of Worcester, see below.

${ }^{121}$ For Oswestry and the Braose recapture of castles in Wales, see below. Note also the argument for a strong sense of community and for the integrity of lordships in the Middle March, in spite of royal efforts to divide the tenants, in B. W. Holden, 'The making of the Middle March of Wales, I066-I250', Welsh History Rev., xx (2000), 207-26.

${ }^{122}$ Cheney, p. 320. Mandeville's fine, although voluntary, had quite impossibly harsh terms, 20,000 marks to be paid within the year. The Barnwell chronicler notes the rather more reasonable sum of 9,000 marks for which Giles de Braose fined for his father's lands, but as the chronicler also refers to the king's restoring of the lands to him, it may be that this represents the fine made in Oct. I2I5 rather than the fine under review in May I2I5. Again, though, the terms of repayment might be just as important as the total amount (Walter of Coventry, ii. 225). 
The Fitz Alans had suffered what seems a blatant injustice. King John had set a fine of I0,000 marks as relief from William Fitz Alan for the land of his father, also William (d. I2I3). In itself, this was unreasonably high for an undisputed succession. However, the king had also agreed a fine of 5,000 marks with Thomas of Erdinton to hold the same land for five years, together with a grant of the marriage of William Fitz Alan to Thomas's daughter. ${ }^{123}$ The exact age of William Fitz Alan is unknown, but his younger brother John, and perhaps another brother, if Osbert Fitz Alan was such, were old enough to be accounted rebels in I215.

In I2II-I2, Robert of Berkeley was made to fine for 2,000 marks to regain his lands after being disseised and was ordered to pay I,Ooo marks almost immediately - terms which he could not keep. Later he was obliged to promise the king ten knights to serve for a year to clear 500 marks of the debt, and even then was threatened with having to negotiate terms for the remaining debt. ${ }^{124}$ Maurice de Gant, lord of Beverstone in Gloucestershire and Hooten Pagnell in Yorkshire, who could also be classified as a 'northerner', was made to account for over $f^{2} 750$ of the debts to the Jews owed by his father-in-law, Henry d'Oilly. ${ }^{125}$ Fulk Fitz Warin had accumulated a whole series of significant debts to the crown by $\mathrm{I} 2 \mathrm{I} 3-\mathrm{I} 4{ }^{126}$

As in the south-west, the royal household and the king's familiares had a firm grip over local office in the Welsh marches. Thomas of Erdinton, household knight and royal ambassador, had been sheriff of Shropshire and Staffordshire since I205, as well as obtaining custody of the Fitz Alan lands in I2I4; William de Cantilupe, royal steward and paymaster, and King John's man since I I98, had been sheriff of Worcestershire since I 207. ${ }^{127}$ But more disturbing than the odd curial sheriff was the unusual concentration of 'alien' sheriffs, castellans and custodians in the Welsh marches. Engelard de Cigogné was sheriff of Gloucestershire and Herefordshire from Michaelmas I 209 to July I 2 I $5 .{ }^{128}$ Peter de Chanceaux was constable of Bristol up to July I2I5; Andrew de Chanceaux was constable of Hereford. ${ }^{129}$ Guy de Chanceaux was custodian of at least significant parts of the honour of Gloucester before it was handed to Geoffrey de Mandeville in I I $4 .{ }^{130}$ Falkes de Bréauté had had charge of Glamorgan before I2I4. Gerard d'Athée had also been sheriff of Gloucestershire and Herefordshire from I 208 to I209, and had had charge of Bristol castle, parts of the honour of Gloucester and control of the

${ }^{123}$ Pipe Roll 16 John, pp. I20-I.

${ }^{124}$ Pipe Roll 14 John, pp. I44-5; Holt, Magna Carta, pp. 192-3.

125 Pipe Roll 16 John, p. 92; Sanders, English Baronies, pp. I4, 55. See also Holt, Northerners, pp. 29, 6I-2.

${ }^{126}$ Pipe Roll 16 John, pp. 40, 72, 89, I20.

${ }^{127}$ List of Sheriffs, pp. II 7, I 57; Church, Household Knights, pp. 9, II , 2I, 26, 64, 66-7.

128 List of Sheriffs, pp. 49, 59.

129 Rot. Litt. Pat., pp. I49b-I50.

${ }^{130}$ Rot. Litt. Claus., i. I35b, I4I, I52, I59. 
Braose lands and castles before his death in I2I $3 .{ }^{131}$ The exclusion from office of many of these men by name in Magna Carta says much about the impact that they had made and complaints about their behaviour remained an issue even after I2I7. Walter de Lacy and William Marshal had found their lands and custodies in the hands of men such as these too. Prising them loose was not always a quick and easy process, even with the king's favour. ${ }^{132}$ The household cabal, with its surfeit of 'aliens', must have seemed as strong in the Welsh marshes as anywhere in the country. ${ }^{133}$

Such a concentration of power in these hands had been created by the peculiar circumstances of I 208-IO, with the fall of William de Braose and the Lacy brothers, together with the earlier eclipse of William Marshal, earl of Pembroke, in I207. ${ }^{134}$ King John had taken some steps backwards since I2I 2 and the plot on his life, but before I2I5 he had not retreated that far. William Marshal's return to favour occurred in the course of I2I2, after initially in that year being presumed an enemy of the king. From I2 I 3 onwards, John gave him Haverford - at first for a fine of I,000 marks, although 500 marks were later pardoned - and the custodies of Cardigan, Carmarthen, Gower and the bishopric of St. Davids. ${ }^{135}$ Walter de Lacy's rehabilitation began with the restoration of his English lands in I2I3, followed in I2I 4 by the grant of the vill, although not the castle, of Ludlow. His Irish lands began to be restored, in return for a 4,000 mark fine in mid I2I5, although negotiations had begun by March I 2 I $5 .{ }^{136}$ As we have already seen, the question of the Braose lands had obviously already been broached, although not settled, by May I2 I 5 , and Geoffrey de Mandeville had gained possession of the honour of Gloucester in I2I4, albeit at the cost of a fine impossible to fulfil. In making concessions, John had won over some people, but not enough to prevent the outbreak of a substantial rebellion in the Welsh marches.

Subsequently, further royal concessions fitfully dismantled the power of the crown as exercised by curial servants in the Welsh marches in favour of local, baronial power. In Herefordshire, Engelard de Cigogné was replaced, initially on I9 July I2Is by Hubert de Burgh. Hubert was certainly a royal familiaris, but at least not an 'alien'. Hubert also replaced Andrew de Chanceaux as castellan of Hereford castle. Then, by I4

131 List of Sheriffs, pp. 49, 59; Holt, Northerners, pp. I84-5; Warren, King John, p. I85. For the honour of Gloucester, see Pipe Roll 10 John, p. I I 4.

132 Rot. Litt. Claus., i. I47, I73b, I75, I82; Warren, King John, p. I85.

${ }^{133}$ Holt, Northerners, pp. 224, 229 n. 2.

${ }^{134}$ B. W. Holden, 'King John, the Braoses, and the Celtic fringe, I207-I6', Albion, xxxiii (200I), I-23, at pp. I, 5-II, I5-I8; Holden, 'Making of the Middle March', pp. 223-4; Warren, 'Painter's King John', p. 3; Painter, Reign of King John, pp. 240-50. For William Marshal, see also D. Crouch, William Marshal: Court, Career and Chivalry in the Angevin Empire, 1147-1219 (Harlow, I990), p. 94; Painter, William Marshal, p. I47.

135 Rot. Litt. Claus., i. I2 Ib-I22, I82b; Rot. Litt. Pat., p. 98b; Crouch, pp. Iо8-го.

136 Rot. Litt. Claus., i. I47, I73b, I75, I9I; Rot. Litt. Pat., p. 99b; Rotuli de Oblatis et Finibus, ed. T. D. Hardy (I835), pp. 562-4. 
August I215, Hubert was in turn replaced by Walter de Clifford junior, the son of a local baron who had been sheriff before the fall of William de Braose. ${ }^{137}$ In August I2 I6, Clifford was succeeded by Walter de Lacy as sheriff. ${ }^{138}$

In Gloucestershire, Engelard de Cigogné was replaced in July I2 I 5 by Ralph Musard, a man closely connected to William Marshal, earl of Pembroke. ${ }^{139}$ Peter de Chanceaux was deprived of Bristol castle, being replaced by Philip d'Aubigny. Admittedly Philip d'Aubigny was a royal captain, dependent on royal appointments and formerly in charge of the Channel Islands, but he had respectable family links, being in some way related to the family of the rebel William d'Aubigny 'Brito' of Belvoir. Philip was to be one of the heroes of the battle of Sandwich and was acceptable enough to be made Henry III's tutor in knightly pursuits after the civil war. ${ }^{140}$ When Philip moved on to play a more general role in the campaigns of I2I7, his replacement at Bristol in April I2I7 was the Poitevin Hugh de Vivonne, already constable at Berkeley in Gloucestershire. Hugh had married the daughter and heiress of the rebel William Malet. ${ }^{141}$ However, despite Hugh de Vivonne's good fortune, the proscribed 'aliens' of Magna Carta had indeed been ejected from the Welsh marches. ${ }^{142}$

In April I2 I6, Ranulf earl of Chester, who in May I2 I5 had already been given the castle of Newcastle-under-Lyme in Staffordshire, was made sheriff of Shropshire and Staffordshire. ${ }^{143}$ Although from September I2 I6 John L'Estrange took over as sheriff, he was a local man of note whose family had settled at Knockin in Shropshire in Henry I's time. At Michaelmas I2 I7, Ranulf earl of Chester regained the sheriffdoms. ${ }^{144}$

The general picture is quite clear. In Shropshire, Herefordshire and Gloucestershire, magnates, local barons and local families had, after I2 I2, and particularly from I2I 5 onwards, reasserted themselves in the region. The men discussed above remained loyal in I2I5-I7, but they need to be associated with figures such as Geoffrey de Mandeville, lord of the honour of Gloucester from I2I4, and with the Braoses. These rebelled, yet also reasserted baronial power. Indeed, in October I2 I5 the Braose question seemed for a short while to be settled. Giles de Braose came to terms with the king and the lands that he did not already hold by then were restored to him. How far this process had been put into effect

137 Rot. Litt. Pat., pp. I49b, I 53; List of Sheriffs, p. 59.

${ }^{138}$ List of Sheriffs, pp. 34, 59, II7, I22, I52.

139 Rot Litt. Pat., p. I48b. For Ralph Musard, see Crouch, pp. I37, I40-I, I95.

${ }^{140}$ Rot. Litt. Pat., pp. 95, I49b-150; Powicke, Henry III and the Lord Edward, i. 9-10. See also Complete Peerage, iv. 93-4.

${ }^{141}$ Vincent, p. I59; Rot. Litt. Claus., i. 300, 305; Rot. Litt. Pat., p. I94.

${ }^{142}$ Holt, Magna Carta, pp. 464-5.

${ }^{143}$ Rot. Litt. Pat., pp. I 37b, I93b.

144 Rot. Litt. Pat., p. I96b; List of Sheriffs, p. II7; D. Walker, Medieval Wales (Cambridge, I990), p. 4I; Davies, pp. 40, 233. 
before Giles's death is not clear. ${ }^{145}$ Although the siege of Rochester had already begun when Giles's peace was made, it seemed as if a general settlement in the Welsh marches might be possible, although it was ultimately not to be.

The revolt in the Welsh marches was in some ways much more serious than the revolt in the south-west, for two reasons: first, the Braose family cause and the personal role of Giles de Braose were of considerable importance in terms of the rebellion as a whole, at least in its initial stages; and second, the revolt in the Welsh marches on the Welsh side of the border was simply so successful. The Welsh sources stress the alliance between, on the one hand, the English barons and, on the other, Llewelyn ab Iorwerth and the other Welsh princes, with Giles de Braose as the linchpin. ${ }^{146}$ In a recent article, Ifor Rowlands has suggested that the surrender of the town and castle of Shrewsbury to Llywelyn ab Iorwerth may have been not only co-ordinated with the entry of 'the Army of God and Holy Church' into London on I7 May I2 I5, but also partially responsible for John's acquiescence to the negotiations leading to Runnymede and Magna Carta. ${ }^{147}$ Whatever the exact timing, between I6 and 25 May I2 I 5, the king was sufficiently worried about the situation in Shropshire to send out a flurry of letters concerned chiefly with the safety of Bridgenorth, the main royal stronghold in the county. ${ }^{148}$ As Giles de Braose was at or near Reading on Io May, it seems likely that his arrangements with the Welsh preceded his journey to join the rebel force at Northampton on 26 April. ${ }^{149}$

Painter suggested that the persecution of the Braose family was 'the greatest mistake John made during his reign'. ${ }^{150}$ King John himself almost confirmed this with the remarkable public justification of his own conduct that he felt the need to issue in I2I2. ${ }^{151}$ Clare, Bohun, Lacy, Mortimer, Ferrers, Port, St. Valery, Clifford - the important families to which the Braoses were related form an impressive list. And if not all of

145 Walter of Coventry, ii. 225, 227; Rot. Litt. Pat., pp. I56b-I57b. Giles's settlement may have been under discussion since July I2 I5 (Holt, Magna Carta, pp. 363-4).

146 'Consules et barones aquilonales cum principibus Walliae contra regem foedera inierunt' (Annales Cambriae, ed. J. W. ab Ithel (I860) (hereafter Annales Cambriae), p. 70); 'yd ymaruolles holl wyrda Loefyr a holl tywyssogyon Kymry y gyt yn erbyn brenhin' (Brut y Tywysogyon: or, The Chronicle of the Princes. Red Book of Hergest Version, ed. T. Jones (Cardiff, I955) (hereafter Brut y Tywysogyon Red Book), pp. 200-I). Brut y Tywysogion: or, The Chronicle of the Princes. Penarth MS. 20 Version, ed. T. Jones (Cardiff, I952) (hereafter Brut $y$ Tywysogion Penarth), p. 90 is less explicit, although a joint struggle is still implied. The author's thanks go to David Thornton of Bilkent University for help with the Welsh language.

147 Rowlands, 'King John and Wales', p. 285.

148 Rot. Litt. Pat., p. I36b.

149 Cheney, pp. 3I4, 320.

${ }^{150}$ Painter, Reign of King John, pp. 249-50.

151 T. Rymer, Foedera, Conventiones, Litterae et . . . Acta Publica, ed. A. Clarke, F. Holbrooke and J. Caley (4 vols. in 7, I8I6-69), I. i. I07-8. For an analysis of the case put by John in this document, see Holden, 'King John, the Braoses, and the Celtic fringe', p. 8. 
these rebelled - Lacy, Mortimer, Ferrers and Clifford remained loyal that does not mean that they had accepted the king's behaviour towards the Braoses, or that they might not consider turning against him. Almost John's last act before dying was to allow Margaret de Braose, daughter of William de Braose (d. I2 I I) and wife of the loyalist Walter de Lacy, to found a religious house for the souls of her father, mother and brother the last two murdered by King John. ${ }^{152}$ Feelings ran strong in this matter even among loyalists.

The Braose rebellion helped bring about the most spectacular royal collapse in the Welsh marches since King Stephen's reign, a damaging blow to John's prestige and, given the importance to Angevin kings of Wales as a recruiting ground, to his potential military power. The alliance of Giles de Braose with the Welsh quickly brought results: 'facto cum ducibus Walliae et baronibus Angliae foedere, terram patris sui cum castellis vi adquisivit, familiaribus regis undique expulsis'. ${ }^{153}$ Note those familiares again.

Giles sent his younger brother, Reginald, to Brycheiniog. With Welsh help, he took the castles of Pencelli, Abergavenny, Llantilio, Grosmont and Skenfrith within three days. ${ }^{154}$ Then Giles himself arrived, presumably having returned from the rebel army that was now in London, to receive the surrender, with no resistance, of the castles of Radnor, Hay, Brecon, Builth and Blaenllyfni. Painscastle, Colwyn and the cantref of Elfael were left to be taken by Gwallter Fychan, son of the one-time Welsh lord of Elfael, Einion Clud. Soon Gower, too, was in Braose hands. ${ }^{155}$ Nor should the rebellion in Shropshire be ignored, even though the sources tell us little. At some stage it seems that Oswestry had been taken either by the Fitz Alans or by the Welsh, or that at least King John had found it untenable. In his expedition to the Welsh borders in the summer of I2 I6, John ordered it to be destroyed, along with Hay and Radnor. ${ }^{156}$ Glamorgan, too, had been lost by the king through the revolt of Geoffrey de Mandeville. Essentially all that was left in Wales in hands loyal to the

152 Rot. Litt. Pat., p. I99b.

153 Annales Cambriae, pp. 70-I.

154 Brut y Tywysogyon Red Book, pp. 202-3; Brut y Tywysogion Penarth, p. 90. Llantilio, Grosmont and Skenfrith had been granted as a fief to William de Braose in I205 (Painter, Reign of King John, p. 45).

155 Gower seems to have been in the possession of Reginald de Braose in I2I7 (Annales Cambriae, p. 7I; Brut y Tywysogion Penarth, pp. 90-2, 95; Brut y Tywysogyon Red Book, pp. 202-5, 2I4-I5). For the attack by the Welsh in I2I5 on Gower, see Brut y Tywysogyon Red Book, pp. 202-5; Brut y Tywysogion Penarth, pp. 90-I; Annales Cambriae, p. 7I; Lloyd, ii. 645 and n. I68. Although generally consistent, the Welsh sources differ in detail and there are problems identifying places, particularly the identification of 'Seinhenydd' as Swansea. The Annales Cambriae has Maelgwn assisting the conquest of Kidwelly, although both versions of the Brut y Tywysogion send him north before that. The Annales Cambriae also has the defenders and burgesses of Carmarthen burning their own town, but Brut y Tywysogion Penarth has this done by the garrison of 'Seinhenydd' and this fits the general accounts better.

156 Brut y Tywysogyon Red Book, pp. 208-9. 
crown was Pembroke and its hinterland and the parts of Gwent in the possession of William Marshal and John of Monmouth. ${ }^{157}$

In early August I2I5, while the Runnymede peace still held, John visited Feckenham, Worcester and Bridgenorth. At the first two places he was still dealing with details of Walter de Lacy's reinstatement in Ireland, while at Bridgenorth he granted Newcastle-under-Lyme to Ranulf earl of Chester, the latter measure, together with the inspection of Bridgenorth itself, part of an attempt to shore up what were now the western limits of his influence. ${ }^{158}$ Both examples demonstrate very clearly how the threat from the rebellion and concessions to loyalist barons in the Welsh marches could go hand in hand.

At no time did King John or the regent seem able even to threaten to reverse the losses in Wales. John's peace agreement with Giles de Braose in October I2I5 should be seen as an admission of defeat. After Giles's death in November I2I5, the Braose lands in John's power were again taken into royal hands. It is significant both that the castle of Bramber had been held by John of Monmouth on behalf of Giles de Braose before his death, and that now all the lands and castles, except for the castle of Knepp and the honour of Bramber in Sussex, were to be held by William Marshal and Walter de Clifford junior. ${ }^{159}$ Reginald de Braose, of course, continued to hold all the lands and castles in Wales, but there is a sense that the rest was being held in trust, in safe baronial hands, for when he made peace.

It should also be noted that Walter de Clifford junior, in the letter quoted above, had been worried about defending Herefordshire against attack from the Welsh; there was no thought of counter-attack. It may have been that the loyal marcher barons were not interested in prosecuting a war against rebel marchers. Around Easter I2 I6, Fulk Fitz Warin was the only named rebel of a number who had made a truce with William Marshal and the other loyal barons of the marches. Painter even suggested that some sort of non-aggression pact had been agreed between William and Reginald de Braose, although only on the basis of the presumably later marriage of William's daughter to Reginald's son. ${ }^{160}$

In May I2 I6, King John was seeking to bring Reginald to accept an arrangement similar to that which had been made with Giles. Among those whose help John sought in this mission were Walter de Lacy, Hugh de Mortimer, John of Monmouth and Walter de Clifford, along with Peter Fitz Herbert, whose lands in Blaenllyfni were in Reginald de Braose's hands and who was soon to rebel himself. ${ }^{161}$ These were men whom Reginald might be expected to trust, but there was to be no successful outcome.

${ }^{157}$ For the other conquests of Llywelyn, see Lloyd, ii. 647-50.

158 Rot. Litt. Pat., pp. I5I-I5Ib, Rot. Chart., p. 2 I 6 b.

159 Rot. Litt. Pat., pp. I59, I59b, I60.

160 Rot. Litt. Claus., i. 270; Painter, Reign of King John, p. 358.

161 Rot. Litt. Pat., pp. I84, I84b; Rot. Litt. Claus., i. 280. 
Between 2I July and I7 August I2 I6, setting off from and returning to Gloucester, the king made an armed progress through the Welsh border lands, visiting Hereford, Hay, Radnor, Leominster, 'Kingesmehed' (between Leominster and Clun), Clun, Shrewsbury, Oswestry, Whitchurch, Shrewsbury, Bridgenorth and Worcester. Apparently unopposed, the expedition was a mixture of intimidation - burning Hay, Radnor and Oswestry - and attempted conciliation - a safe conduct was issued for Reginald de Braose and approaches were made to some local Welsh leaders. ${ }^{162}$ However, beyond showing that the rebels could not face the king's main force, it seems to have achieved little.

The regent, too, pursued reconciliation with Reginald in March I 2 17. ${ }^{163}$ Nothing could be achieved militarily in Wales while the war continued in England. ${ }^{164}$ Apart from a brief visit to Goodrich castle, Chepstow and Usk in July I2 I7, after Reginald de Braose had made peace in June, the regent got no nearer Wales than Gloucester and Tewkesbury. ${ }^{165}$ That Reginald rebuffed all approaches from King John and the regent until June I 2 I probably had less to do with the terms of peace than with the question of trust, and Reginald's desire to avoid breaking his alliance with Llywelyn, sealed by his marriage to Llywelyn's daughter. ${ }^{166}$

On their own, the successes of the Braoses and of Llywelyn in Wales, however dramatic, could hardly threaten the survival of the Plantagenet dynasty. There is no denying that King John and the regency did have powerful baronial support in the region, from the likes of Ranulf earl of Chester, William Marshal, earl of Pembroke, Henry Fitz Count, Walter de Lacy, Hugh de Mortimer, Robert de Mortimer, the Cliffords and John of Monmouth. We may, however, question how solid and how principled the loyalty of this group was. Too much has been made of William Marshal's own propaganda as regent and the afterthoughts of his biographer as to William's 'deep essential loyalty'. ${ }^{167}$ This was never really put to the test before William threw the dice at Lincoln and won. In any case, others had to remain loyal as well.

Although in general there seems to have been less of a strengthening of the rebellion in the summer of I2I6 in the Welsh marches than there was in the south-west, Prince Louis might have come to the Welsh marches, or at least John certainly thought so. In mid August I2 I6, the

162 Rot. Litt. Claus., i. 277b-282; Rot. Litt. Pat., pp. I9I-I93b; Brut y Tywysogyon Red Book, pp. 208-9. Given the apparent absence of prisoners, it seems more likely that King John took Hay and Radnor unopposed than that he besieged them, as in Brut y Tywysogion Penarth, p. 93.

163 Pat. Rolls 1216-25, pp. 4I-2.

164 It was not until late Sept. or early Oct. I2 I7 that Caerleon was captured by William Marshal's bailiff, probably John de Earley (Crouch, p. I28; Rot. Litt. Claus., i. 330).

165 Pat. Rolls 1216-25, p. 79.

166 Llywelyn did take action against Reginald when he returned to Henry III's allegiance and Reginald had to give up Swansea to get peace (Lloyd, ii. 645, 652).

167 Painter, Reign of King John, p. 250; Carpenter, Minority of Henry III, pp. 3 I-2. 
king issued special instructions to John Marshal at Worcester and Walter de Lacy at Hereford, not to allow themselves to be trapped inside their castles by Louis's army. ${ }^{168}$ Partly, perhaps, this was a precaution needed because of John's planned and final, as it turned out, expedition to East Anglia and Lincolnshire, but it shows how potentially fluid the situation was.

An example of this, and of the ambivalent position of the loyalist barons in the Welsh marches, is provided by the brief rebellion of Walter de Beauchamp in Worcestershire. On I9 August I2 I5 letters patent had been issued replacing William de Cantilupe, one of King John's household men, with Walter de Beauchamp as sheriff of Worcestershire. ${ }^{169}$ This was an order that, as we have seen, fits into a pattern of changes to the sheriffs of western England following Magna Carta, but these particular letters did not take effect. Presumably with John's collusion or at least toleration, William de Cantilupe continued in possession of the sheriffdom. Almost a year later, at some point in July I2 I6, with the king's fortunes at a low ebb, Walter de Beauchamp, with a considerable following, rebelled, and together with William Marshal junior, seized Worcester. This outbreak of rebellion was quickly suppressed through the action of Ranulf earl of Chester, Falkes de Bréauté and William Marshal senior. ${ }^{170}$ A number of Walter de Beauchamp's followers were captured, including a Roger Corbet and Hugh de Pointz, son of the Gloucestershire rebel Nicholas de Pointz. ${ }^{171}$ But the aftermath is very interesting. William de Cantilupe was replaced as sheriff by John Marshal, to whom control of the forest of Worcester was also transferred. ${ }^{172}$ After Walter's submission, he was quickly and fully restored to his lands, as were many of his followers, and during the process of making his submission and obtaining his absolution from the legate his lands were transferred from William de Cantilupe to the 'respectable' hands of Walter de Lacy, Hugh de Mortimer, Walter de Clifford and John of Monmouth. ${ }^{173}$ In March I 217 Walter de Beauchamp himself was made sheriff of Worcestershire and custodian of the forest of the county. ${ }^{174}$ The conclusion that Walter's rebellion was to some extent thought excusable by the principal loyalist barons, and that the problem was dealt with 'their way', is inescapable.

If one seeks to compare the rebellions in south-western England and in the Welsh marches with each other and with the northern rebellion as analysed by Holt, one has to acknowledge that each region necessarily had its own set of individual actors, its own structures of lordship and

168 Rot. Litt. Pat., p. I94.

169 Rot. Litt. Pat., p. I 53b; List of Sheriffs, p. I 57.

170 Painter, William Marshal, pp. I87-8; Annales Monastici, ed. H. R. Luard (5 vols., Rolls ser., I 864-9) (hereafter Annales Monastici), i. 62, iv. 406-7.

171 Annales Monastici, i. 62; Rot. Litt. Claus., i. $280 \mathrm{~b}$.

172 Rot. Litt. Pat., pp. I93b, I94.

173 Rot. Litt. Pat., p. I92b; Rot. Litt. Claus., i. 280 b.

174 John Marshal was allowed to retain the manor of Feckenham, which had been attached to the forest (Pat. Rolls 1216-25, pp. 37-8). 
government, and its own history. Nevertheless, it is striking how applicable Holt's conclusions about the northern rebellion are to the revolts in the other two regions. The problems - grievances, individual and collective, over the king's handling of patronage and administrative office; an unaccustomed financial pressure from the king; the behaviour of the 'king's friends'; and a local society's resentment at intrusion by outsiders - certainly were not exclusive to the northern counties of England. Regarding the question of the importance of honorial loyalties in the rebellion, the evidence presented here provides a little extra ammunition for both sides of the debate, but, as suggested in the introduction, cannot really help to decide it.

Individual grievances and honorial solidarities played a more significant role in bringing about a substantial rebellion in the Welsh marches than in the south-west. In part, this was because of a somewhat different structure of landholding, with more powerful, often relatively compact baronies and lordships, and because of such important individual grievances as those of the Braose and Fitz Alan families. Geoffrey de Mandeville's lordship of the honours of Gloucester and Glamorgan, and the huge fine that he owed for those lands, was also significant. If the fine were to be paid, or even any considerable part of it, it would no doubt have fallen, perhaps quite heavily, on the tenants of these honours. The number of rebel tenants of these honours may also have had much to do with unhappiness at their past treatment while the honours were in royal hands, at the mercy of men like Falkes de Bréauté, Gerard d'Athée and Guy de Chanceaux.

In the Welsh marches, we do not see such strong evidence of the collective feelings of county society as in the south-west. Yet, taking into account the royal decisions made to head off rebellion and to encourage the loyalty of men like Ranulf earl of Chester, Walter de Clifford junior, Walter de Lacy and of course William Marshal, we can see the power of King John's household and favourites in both south-western England and the Welsh marches as a common theme in the causes of the rebellion. In the Welsh marches, the 'alien' element in this household dominance of local government was particularly strong, and evidently particularly irksome. More generally, the aggressive behaviour of men like William Briwerre, Hugh de Neville, Gerard d'Athée, Engelard de Cigogné and Falkes de Bréauté could provide a common cause between rebel marcher lordships and the communities represented in phrases like 'the men of Cornwall', 'the men of Devon' or 'the men of Dorset and Somerset'. ${ }^{175}$ In both areas it also linked the cause of the rebels to that of the loyalist barons, albeit pursued by other means.

175 Although Hugh de Neville became a rebel in June I216, his earlier enforcement of the forest law had obviously been feared in Devon (Pipe Roll 11 John, p. 92). Geoffrey de Mandeville had had his own clash with William Briwerre (Holt, Northerners, p. 80 n. 3). 
In terms of the results of the rebellions in south-western England and the Welsh marches, there are again similarities in that both strengthened baronial power against the central government. This was perhaps of special significance in the Welsh marches. The prominence of the marcher barons in the politics of England throughout Henry III's reign was in a sense created, or recreated, by the outcome of the struggle from I 2 I 5 to I2I7 and by that struggle's prelude in John's concessions of the period I2I2-I5.

As has sometimes been argued, the re-issue of Magna Carta in November I2 16, modified and without its security clause, may not simply have been a question of expediency. William Marshal, earl of Pembroke, and Ranulf earl of Chester, along with their supporters, had good reason to be genuinely in favour of the modified document, having at times suffered from arbitrary kingship and being vulnerable to the overexploitation of royal lordship. ${ }^{176}$ With reference to Magna Carta, in all of its forms, in its expressions both of community and of its limitations and prohibitions on the behaviour of government towards individuals, it would be wrong to draw too clear a distinction between the grievances of individuals like Giles and Reginald de Braose, or of Geoffrey de Mandeville or the Fitz Alans, or indeed of more minor figures, and the complaints of local communities, or indeed of the community of the realm. What could happen to one could happen to all, and protection for all would mean nothing without protection of the individual's rights from arbitrary royal action.

${ }^{176}$ See, e.g., Carpenter, Minority of Henry III, pp. 23-4. 
Table 1. Baronial rebels in south-western England

\begin{tabular}{|c|c|c|c|}
\hline Barony & $\mathrm{KF}^{\mathrm{a}}$ & Holder & Behaviour $^{\mathrm{b}}$ \\
\hline Bampton (Dev.) & $7-$ IO & William Paynel & R. Apr. I2I6 L. March I2I $7^{177}$ \\
\hline Berry Pomeroy (Dev.) & 32 & Henry de Pomeroy & R. post-March I2I6 L. Sept. I2 I6 $6^{178}$ \\
\hline Castle Cary (Som.) & $8-19$ & Henry Lovel & L. Aug. I 2 I $6^{179}$ \\
\hline Castle Combe (Wilts.) & $2 \mathrm{I}$ & Walter de Dunstanville & L. Nov. I 2 I $7^{180}$ \\
\hline Chiselborough (Som.) & IO-I 8 & John de Montague & R. by Oct. $1215^{181}$ \\
\hline Chitterne (Wilts.) & $40-58$ & William earl of Salisbury & R. May I2I6 L. March I2 I $7^{182}$ \\
\hline Curry Malet (Som.) & $22-25$ & William Malet & R. I2I5 d. Dec. I2I $5^{183}$ \\
\hline Elston (Wilts.) & 9 & Elias Giffard & L. March I $2 \mathrm{I} 7^{184}$ \\
\hline Great Torrington (Dev.) & $29-30$ & William Fitz John & R. by Aug. I 2 I $6^{185}$ \\
\hline Keevil (Wilts.) & 9 & John Fitz Alan & R. I2I5 L. Nov. I2I $7^{186}$ \\
\hline Marshwood (Dors.) & I5 & Robert de Mandeville & R. I2I5 L. May I2I $7^{187}$ \\
\hline Nether Stowey (Som.) & IO-I I & Philip de Columbars & L. May I $2 \mathrm{I} 7^{188^{\circ}}$ \\
\hline \multirow[t]{2}{*}{ Poorstock (Dors.) } & $30-3 I$ & Robert Fitz Pain $(1 / 2)$ & R. I2I5 L. June I2I $7^{189}$ \\
\hline & & Robert de Newburgh $(1 / 2)$ & L. Aug. $1217^{190}$ \\
\hline Stogursey (Som.) & $4 \mathrm{I}-46$ & Warin Fitz Gerold & R. July I2 I6 L. Jan. I 2 I $7^{191}$ \\
\hline \multirow[t]{2}{*}{ Trowbridge (Wilts.) } & $3 \mathrm{I}-4 \mathrm{O}$ & William earl of Salisbury & R. May I2I6 L. March I2 I $7^{192}$ \\
\hline & & Henry de Bohun, earl of Hereford & R. May I2I5 L. Nov. I2 I7 ${ }^{193}$ \\
\hline Winterbourne St. Martin (Dors.) & $25-3 \mathrm{I}$ & Alured of Lincoln & L. March I 2 I $7^{194}$ \\
\hline
\end{tabular}

${ }^{a}$ In this and the following tables, the columns headed 'KF' indicate the approximate number of knight's fees answerable to the barony. The figures are taken from the notes to the list of baronies and probable baronies in I. J. Sanders, English Baronies: a Study of their Origins and Descent 1086-1327 (Oxford, I966) and from T. K. Keefe, Feudal Assessments and the Political Community under Henry II and his Sons (Berkeley, Calif., I983), apps. II, III, pp. I54-90, using servitia debita, inquisitions of knight-service and scutage demands. They can only be a very rough guide to the wealth and importance of the different baronies. ${ }^{\mathrm{b}}$ In the tables of baronial rebels R. + date indicates the date of rebellion, if known; L. + date indicates the date of return to King John's or Henry III's allegiance. 
177 Rot. Litt. Claus., i. 26Ib, 30ob. William Paynel also held four knight's fees of the honour of Wallingford (Rot. Litt. Claus., i. 262b; Red Book of the Exchequer, ii. 598).

178 Church, Household Knights, p. I I0; Rot. Litt. Claus., i. 287. In a letter close of Feb. I2I 8 it was alleged that a Richard de Crues had earlier, against his will, been made to rebel by Henry de Pomeroy (Rot. Litt. Claus., i. 352b).

179 A Henry 'Luvell' was reseised after Walter de Beauchamp's rebellion and return to loyalty in July-Aug. I2I6. If this was the Henry Lovel (d. I2I6) who held the barony of Castle Cary in Somerset, he must at least have been in rebellion for a short time (Sanders, English Baronies, p. 27; Rot. Litt. Claus., i. 28ob). In Dec. I216, the sheriff of Dorset and Somerset was ordered to reseise Christiana, the wife of Henry 'Lupell', if he 'had not been against King John' (Rot. Litt. Claus., i. 295). See also Complete Peerage, viii. 202.

180 Walter seems to have been at peace with the king in Dec. I 2 I 5 , although apparently after an earlier rebellion (Rot. Litt. Claus., i. 24I, 34I).

181 His lands were given to Godfrey of Craucumbe in Oct. I2 I 5 (Rot. Litt. Claus., i. 233). He was 'with the enemies of the king' at the beginning of Sept. I2 I6 (Rot. Litt. Pat., pp. I96-I96b).

182 Walter of Coventry, ii. 23 I, 235; Rot. Litt. Claus., i. 299; Painter, King John, p. 375; Carpenter, Minority of Henry III, p. 27. Both W. L. Warren and R. V. Turner suggest that William earl of Salisbury returned to King John's allegiance before the king's death, but this statement depends on a probably misplaced entry in the Dunstable annals (Warren, King John, p. 253; Turner, King John, p. 257; Annales Monastici, iii. 47).

${ }^{3} 3$ Sanders, English Baronies, pp. 38-9. A prominent early rebel in I2I5 and one of Magna Carta's Twenty-Five, he died, leaving three daughters, probably before 20 Dec. I2 I5 (Painter, Reign of King John, pp. 289, 307, 3 I0; Holt, Magna Carta, pp. 478, 480). King John had tried to negotiate with both William Malet and Robert Fitz Pain of Poorstock, Dorset, as early as 25 May I2 I5, but this apparently came to nothing (Rot. Litt. Pat., p. I38b). For the date of William's death, see Rot. Litt. Pat., p. I6Ib; Rot. Litt. Claus., i. 243.

184 Rot. Litt. Claus., i. 299. The date may suggest that Elias Giffard was following the earl of Salisbury, at least in his return to Henry III's service.

185 Rot. Litt. Claus., i. 283b. Great Torrington had been for a time in the custody of William de Braose (Painter, Reign of King John, p. 44).

${ }^{186}$ The barony of Keevil was the property of the Shropshire Fitz Alan family - William Fitz Alan and subsequently his brother and heir, John Fitz Alan (Sanders, English Baronies, pp. 7I, I24). Although listed here as a rebel barony, William Fitz Alan and his lands were in the hands of the king's custodian, Thomas of Erdinton, although this did not stop John Fitz Alan and his relatives from being rebels. The dates given here concern John Fitz Alan. He and Osbert Fitz Alan are listed by Roger of Wendover as at Stamford, and Osbert was excommunicated by Innocent III. John Fitz Alan was a reversus in Nov. I2I7 (Chronica Majora, ii. 585, 644; Rot. Litt. Claus., i. 343b).

187 A rebel in I2I5, excommunicated by Innocent III and in the king's prison by Oct. I2 I 5 , received writs of reseisin for all four of the south-western counties in May I2I7 (Chronica Majora, ii. 644; Rot. Litt. Claus., i. 233, 308).

188 Rot. Litt. Claus., i. 308. One of his relatives, Robert de Columbars, had made his peace with Henry III's regency council in March I2I7. Another, William de Columbars, did so perhaps around the time of the final settlement of war (Rot. Litt. Claus., i. 30ob, 373b).

189 Painter, Reign of King John, pp. 289, 307, 3 IO. He seems to have been negotiating with the king in Sept. I2I5 and in July I2 I6, but he was given a writ of reseisin for land in Staffordshire only in June I2I7, and in the same month Peter de Maulay was informed that he was faithfully in Henry III's service (Rot. Litt. Pat., pp. I55, I9I; Rot. Litt. Claus., i. 3 I I, 3 I2b).

${ }^{190}$ Rot. Litt. Claus., i. 319.

191 With land in many other counties, he rebelled perhaps in July I2 I6 and returned to Henry III's faith and service by 2 Jan. I2 I7, one of the first major defections from Prince Louis after King John's death (Rot. Litt. Claus., i. 295; Rot. Litt. Pat., p. I9ob; Carpenter, Minority of Henry III, p. 25, n. 3).

192 Painter, Reign of King John, pp. 374-5; Rot. Litt. Claus., i. 299.

193 Rot. Litt. Claus., i. 200, 374b. Henry was captured at the battle of Lincoln (Gervase of Canterbury, ii. III).

194 Rot. Litt. Claus., i. 302. As letters for Alured were also addressed to William earl of Salisbury, who on 5 March had himself returned to Henry III's service, and Alured did probably hold land from the earl, it is possible that Alured had simply followed the earl into and out of rebellion (Carpenter, Minority of Henry III, p. 27; Red Book of the Exchequer, i. 240). 
Table 2. Loyal barons in south-western England

\begin{tabular}{lcl}
\hline Barony & KF & \multicolumn{1}{c}{ Holder } \\
\hline Barnstable (Dev.) & $24-3 \mathrm{I}$ & Henry de Tracy \\
Bradninch (Dev.) & $20-30$ & Henry Fitz Count \\
Cardinham (Corn.) & $7 \mathrm{I}$ & Robert of Cardinham \\
Erlestoke (Wilts.) & $?$ & Matthew Fitz Herbert ${ }^{196}$ \\
North Cadbury (Som.) & I7-I9 & James of Newmarket ${ }^{197}$ \\
Okehampton (Dev.) & $93-\mathrm{IOO}$ & Robert de Courtenay \\
Plympton (Dev.) & $60-\mathrm{I} 3 \mathrm{I}$ & William de Redvers earl of Devon \\
Tarrant Keynston (Dors.) & $3-6$ & William de Kaines \\
Totnes (Dev.) & $54-76$ & Henry Fitz Count $\left({ }^{1} / 2\right)$ \\
& & Reginald de Vautorte $\left({ }^{1} / 2\right)$ \\
Trematon (Corn.) & 59 & Reginald de Vautorte \\
West Dean (Wilts.) & $20-25$ & John of Monmouth $\left({ }^{1} / 3\right)$ and others ${ }^{198}$ \\
\hline
\end{tabular}

195 Henry had been granted the formerly Braose half of the honour in I2 I3, and given the rebellion of Reginald de Braose and his claims to half of Barnstaple, one would expect Henry to be on King John's side (Sanders, English Baronies, p. I04). However, the question is complicated by the fact that a Henry de Tracy had joined the rebellion by Aug. I2I6. His lands, along with those of William of (Great) Torrington were granted to William Briwerre junior (Rot. Litt. Claus., i. 283b). It seems likely that this is a different branch of the Tracy family. A William de Tracy was with the king's enemies in Feb. I2I6 and his lands had been given to his presumably then loyal lord, William of Torrington (Rot. Litt. Claus., i. 249b). It is possible that the rebel Henry de Tracy was the same who had lost the honour of Bradninch in I2O2 (Sanders, English Baronies, p. 20). On the other hand, there was the possibility of conflicts between loyalists: the Barnstaple Tracys had also made a claim for Bradninch (Painter, Reign of King John, pp. 38-8, 42-3).

196 It is not clear exactly when Matthew Fitz Herbert acquired the barony of Erlestoke through marriage (Sanders, English Baronies, p. 42). Although he seems to have remained loyal to the Plantagenets throughout, his brother (presumably), Peter Fitz Herbert, rebelled in the summer of I2I6 (see below). Matthew was one of those who advised the king in the production of Magna Carta I2I5 and Magna Carta I2I6. He also later witnessed the I225 reissue (Holt, Magna Carta, pp. 448, 50I, 5II).

197 In Aug. I2 I6, John Russell was granted seisin of the lands of the king's enemies of the fief of James of Newmarket, lord of the barony of North Cadbury, who had recently died. This does not mean that James himself had been a rebel, but it suggests that there were rebels among his tenants (Rot. Litt. Claus., i. $28 \mathrm{Ib}$ ). John Russell's son, Ralph, married one of James's two daughters and heiresses (Sanders, English Baronies, p. 68). There was at least one rebel amongst the Russell family, a William Russell with lands in Gloucestershire (Rot. Litt. Claus., i. 334$)$.

198 One of the heiresses, Joan, married a rebel, William de Neville, but only after the end of the civil war (Sanders, English Baronies, p. 96; Rot. Litt. Claus., i. 300b, 339b, 340). 
222 Rebellion in south-western England and the Welsh marches, 1215-17

Table 3. Baronial rebels in the Welsh marches

\begin{tabular}{|c|c|c|c|}
\hline Barony & $\mathrm{KF}$ & Holder & Behaviour \\
\hline Abergavenny & I 3 & Giles de Braose & $\begin{array}{l}\text { R. May I } 2 \text { I } 5 \\
\text { L. Oct. I } 2 \text { I } 5^{199}\end{array}$ \\
\hline & & Reginald de Braose & $\begin{array}{l}\text { R. May I } 2 \text { I } 5 \\
\text { L. June } 12 \mathrm{I} 7^{200}\end{array}$ \\
\hline Berkeley (Glos.) & 5 & Robert of Berkeley & $\begin{array}{l}\text { R. I2 I5 L. March- } \\
\text { June I2I } 7^{201}\end{array}$ \\
\hline Beverstone (Glos.) & I & Maurice de Gant & $\begin{array}{l}\text { R. May I } 215 \\
\text { L. Nov. I } 217^{202}\end{array}$ \\
\hline Blaenllyfni (Brec.) & I $3-27^{203}$ & Peter Fitz Herbert & $\begin{array}{l}\text { R. May-Aug. I2I6 } \\
\text { L. Aug. I2 I } 7^{204}\end{array}$ \\
\hline Brecon (Brec.) & 25 & $\begin{array}{l}\text { Giles de Braose } \\
\text { Reginald de Braose }\end{array}$ & $\begin{array}{l}\text { See above } \\
\text { See above }\end{array}$ \\
\hline Caldicot (Mon.) & I $5^{205}$ & $\begin{array}{l}\text { Henry de Bohun, earl } \\
\text { of Hereford }\end{array}$ & $\begin{array}{l}\text { R. May I2I5 } \\
\text { L. Nov. I } 217^{206}\end{array}$ \\
\hline $\begin{array}{l}\text { Castle Holgate } \\
\text { (Salop.) }\end{array}$ & 5 & Thomas Mauduit & $\begin{array}{l}\text { R. Sept. I } 2 \text { I } 5 \\
\text { L. Sept. } 1217^{207}\end{array}$ \\
\hline Cause (Salop.) & 5 & Robert Corbet & L. Nov. $1217^{208}$ \\
\hline Clun (Salop.) & $9-\mathrm{I} 7$ & John Fitz Alan & $\begin{array}{l}\text { R. I2I5 } \\
\text { L. Nov. I2I } 7^{209}\end{array}$ \\
\hline Colwyn & 46 & $\begin{array}{l}\text { Giles de Braose } \\
\text { Reginald de Braose }\end{array}$ & $\begin{array}{l}\text { See above } \\
\text { See above }\end{array}$ \\
\hline Glamorgan (Glam.) & 47 & $\begin{array}{l}\text { Geoffrey de Mandeville } \\
\text { Isabelle of Gloucester }\end{array}$ & $\begin{array}{l}\text { R. May I2I5 } \\
\text { d. March I } 26^{210} \\
\text { L. Sept. I } 27^{211}\end{array}$ \\
\hline Gloucester (Glos.) & $262-75$ & $\begin{array}{l}\text { Geoffrey de Mandeville } \\
\text { Isabelle of Gloucester }\end{array}$ & $\begin{array}{l}\text { See above } \\
\text { See above }\end{array}$ \\
\hline Gower (Glam.) & 27 & $\begin{array}{l}\text { Giles de Braose } \\
\text { Reginald de Braose }\end{array}$ & $\begin{array}{l}\text { See above } \\
\text { See above }\end{array}$ \\
\hline Kington (Heref.) & $\mathrm{IS}^{212}$ & $\begin{array}{l}\text { Giles de Braose } \\
\text { Reginald de Braose }\end{array}$ & $\begin{array}{l}\text { See above } \\
\text { See above }\end{array}$ \\
\hline $\begin{array}{l}\text { Much Marcle } \\
\text { (Heref.) }\end{array}$ & I & John de Ballon & $\begin{array}{l}\text { R. July I } 2 \text { I } 6 \\
\text { L. June } 1217^{213}\end{array}$ \\
\hline Oswestry (Salop.) & I9 $-28^{214}$ & John Fitz Alan & See above \\
\hline Radnor (Rad.) & 6 & $\begin{array}{l}\text { Giles de Braose } \\
\text { Reginald de Braose }\end{array}$ & $\begin{array}{l}\text { See above } \\
\text { See above }\end{array}$ \\
\hline Salwarpe (Worcs.) & $7-\mathrm{I} 6$ & Walter de Beauchamp & $\begin{array}{l}\text { R. July I2 I } 6 \\
\text { L. Aug. I2 I } 6^{215}\end{array}$ \\
\hline Tarrington (Heref.) & $5-10$ & $\begin{array}{l}\text { Walter of Stokes }(1 / 4) \\
\text { Ralph Belet }(1 / 4)\end{array}$ & $\begin{array}{l}\text { R. I2I } 5^{216} \\
\text { R. by Nov I } 2 \text { I5 } \\
\text { L. Apr } 1217^{217}\end{array}$ \\
\hline
\end{tabular}


199 Walter of Coventry, ii. 2 I9; Rot. Litt. Claus., i. 232b; Rot. Litt. Pat., pp. I56b, I57b.

200 Brut y Tywysogyon Red Book, pp. 202-3; Brut y Tywysogion Penarth, p. 90; Rot. Litt. Claus., i. 3 I Ib.

$201 \mathrm{He}$ was excommunicated by Innocent III. There seems to have been an attempt to negotiate with him in July I2I6, when the king was at Berkeley, but Robert only seems to have returned to Henry III's allegiance by I5 March I2I7. An order to restore his lands in Gloucestershire and Somerset was issued at this time. However, the details agreed with the regent, William Marshal - the vill and castle of Berkeley were kept in royal hands, with Robert having to make a contribution of $f 40$ to pay for the guarding of the castle - were still being worked out in mid June I2I7. Robert also had lands in Devon that were restored at this time (Chronica Majora, ii. 644; Rot. Litt. Pat., p. I9I; Rot. Litt. Claus., i. 300, 3 I I, 3 I Ib; Painter, Reign of King John, pp. 289, 292). A royal constable held Berkeley castle at least from Aug. I2I6, when it was ordered that Nicholas of Yealand, who had been disseised by Robert of Berkeley, presumably for not supporting the rebels, be restored to the lands he held of Robert. However, the lack of his castle had evidently not brought Robert to heel (Rot Litt. Claus., p. 283b).

202 An early and prominent rebel, often regarded as a 'Northerner' and captured at the battle of Lincoln. Like Robert of Berkeley, he was a grandson of Robert Fitz Harding, in addition to being the nephew of the northern rebel, Gilbert de Gant (Chronica Majora, ii. 585, 644; Gervase of Canterbury, ii. I I I).

203 The higher figure includes the Fitz Herbert share of the Miles of Gloucester inheritance.

204 A third portion of the lands originally held by Miles of Gloucester, consisting mainly of the honour of Blaenllyfni, had come to Peter Fitz Herbert. He had begun as active on the royal side, had been one of King John's advisers at the time of Magna Carta and had remained loyal to King John as late as May I2 I6, despite the loss of Blaenllyfni castle to Giles de Braose, bishop of Hereford, in May I215. Yet by Aug. I2I6 he had gone over to Prince Louis and remained on the rebel side at least until July I2I7, although Gervase of Canterbury has him escaping capture in the aftermath of the naval battle of Sandwich in Aug. I2I7 (Sanders, English Baronies, pp. 7-8; Lloyd, ii. 644, 65I and n. 200; Holt, Magna Carta, p. 448; Rot. Litt. Claus., i. 280, 3I4, 3 I6, 320b; Gervase of Canterbury, ii. II2).

205 The figure represents the Bohun share of the Miles of Gloucester inheritance. The author has no information on any Welsh fees.

206 Rot. Litt. Claus., i. 200, 374b. Henry was captured at the battle of Lincoln (Gervase of Canterbury, ii. III).

207 A little after Thomas's rebellion, the castle of Holgate itself was assigned to Hugh de Mortimer (Rot. Litt. Claus., i. 285, 287b, $32 \mathrm{Ib}$ ).

208 Robert Corbet himself does not seem to have been an active rebel, but he was disseised on account of his rebel son, Thomas. Roger Corbet was captured at Worcester in early Aug. I2 I6. The lands and castle of Cause had apparently been taken into the earl of Chester's hands and Robert was only reseised in Nov. I2I7 (Pat. Rolls 1216-25, p. I27; Rot. Litt. Claus., i. $28 \mathrm{ob})$.

${ }^{209}$ The baronies of Clun and Oswestry were the property of the Shropshire Fitz Alan family - William Fitz Alan and subsequently his brother and heir, John Fitz Alan (Sanders, English Baronies, pp. 7I, II2). See above, n. I84, for the Fitz Alans.

${ }^{210}$ Walter of Coventry, ii. 219; Holt, Magna Carta, p. 478; Chronica Majora, ii. 643; Histoire des Ducs de Normandie, p. I64.

211 Rot. Litt. Claus., i. 322.

212 The figure here represents the Braose share of the Miles of Gloucester inheritance.

213 Rot. Litt. Claus., i. 278, 3 I Ib. John de Ballon was ultimately descended from William

Fitz Osbern and from the first lord of Abergavenny, Hamelin de Ballon. For the complicated Ballon family history, see J. H. Round, 'The family of Ballon and the conquest of South Wales', in J. H. Round, Studies in Peerage and Family History (I90I), pp. I8 I-2 I 5.

214 The figure excludes the fees already counted for Keevil, Wiltshire.

215 Annales Monastici, i. 62, iv. 406-7; Painter, Reign of King John, p. 375; Painter, William Marshal, pp. I87-8; Rot. Litt. Claus., i. 280b, 282; Rot. Litt. Pat., pp. I92b, I93b, I94.

216 Cal. Anc. Corresp. Wales, p. I.

217 Rot. Litt. Claus., i. 238, 306b. 
Table 4. Loyal barons in the Welsh marches

\begin{tabular}{lcl}
\hline Barony & KF & \multicolumn{1}{c}{ Holder } \\
\hline Chepstow (Mon.) & $66^{218}$ & William Marshal, earl of Pembroke \\
Chester (Ches.) & I $8^{219}$ & Ranulf earl of Chester \\
Clifford (Heref.) & IO & Walter de Clifford \\
Dudley (Worcs.) & $50-56$ & Ralph de Somery \\
Dursley (Glos.) & 8 & Roger of Berkeley \\
Ewyas Harold (Heref.) & I9-23 & Roger de Clifford \\
Kempsford (Glos.) & I 3 & Pain of Chaworth 220 \\
Monmouth (Mon.) & I 5 & John of Monmouth \\
Pembroke (Pem.) & I7 & William Marshal \\
Pulverbatch (Salop.) & I & Hugh of Kilpeck \\
Richard's Castle (Heref.) & 23 & Robert de Mortimer \\
Snodhill (Heref.) & I3-I7 & Robert of Chandos \\
Sudeley (Glos.) & I-3 & Ralph of Sudeley \\
Tarrington (Heref.) & $5-$ IO & Godfrey of Crawcombe $(1 / 4)$ \\
& & Richard le Brun $(1 / 4)$ \\
Wem (Salop.) & 5 & Hugh Pantolf \\
Weobley (Heref.) & 5 I-62 & Walter de Lacy \\
Wigmore (Heref.) & I-2 221 & Hugh de Mortimer \\
\hline
\end{tabular}

218 This figure does not include any Welsh fees.

219 A figure for Cheshire itself and Wales was given as 80 . The figure here excludes baronies such as Bolingbroke and Richmond, based outside the region.

${ }^{220}$ Pain has some relevance to south-western England too. He was one of those sent by the king to discuss Salisbury castle with the earl of Salisbury in June I2I6, round about the time of the earl's transfer of his allegiance to Prince Louis (Rot. Litt. Pat., pp. I87n, I88). Pain was also with the king at Corfe castle on I4 July I2I6 (Rot. Litt. Pat., pp. I9ob, I9I).

221 The figure does not include any Welsh fees. 